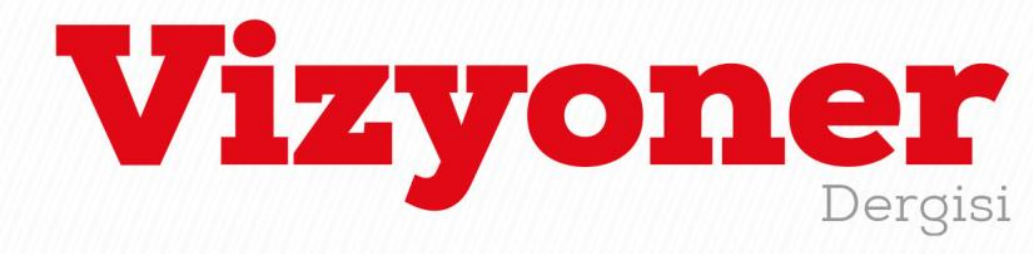

Süleyman Demirel Üniversitesi Vizyoner Dergisi, Yıl: 2021, Cilt: 12, Sayı: 30, 393-416.

Süleyman Demirel University Visionary Journal, Year: 2021, Volume: 12, No: 30, 393-416.

\title{
THE EFFECT OF FAMILY FINANCIAL SOCIALIZATION LEVELS ON MONEY ATTITUDES OF UNIVERSITY STUDENTS*
}

\section{ÜNIVERSITE ÖĞRENCILLERININ AİLE FINANSAL SOSYALLEŞME DÜZEYLERİNIN PARA TUTUMLARINA ETKISI}

\author{
Asst. Prof. Dr. Bilgehan KÜBİLAY ${ }^{1}$ \\ Lecturer Dr. Özgür TUNÇEL ${ }^{2}$
}

\begin{abstract}
The purpose of the study is to manifest university students' relationships with money not only in terms of their family financial socialization levels, but also in terms of their demographic and socio-economic characteristics. Moreover, in order to measure family financial socialization levels of university students, a new two-dimensional scale, which is composed of "financial experience and learning" and "money management skills", is developed. The study is crucial in that it is most likely to create positive financial behaviours between parents and students by means of developing informal education in family. Besides, the research is highly likely to become beneficial for creating new financial education programs in educational institutions particularly on the issues of money attitudes and financial socialization. As far as the cause and effect relationships are concerned, it is detected that students' worries about savings and financial literacy decreased inasmuch as their financial experiences and learning increased. In addition to this result, it is observed that students' mindful and responsible attitude increased in that their money management skills increased. Finally, it is ascertained significant differences between family financial socialization and demographic and socio-economic characteristics and also between money attitudes and demographic and socio-economic characteristics.
\end{abstract}

Keywords: Family Financial Socialization, Money Management Skills, Financial Experience, Financial Literacy, Money Attitude.

JEL Classification Codes: G40, D10, D14, G53, Z13.

ÖZ

Araştırmanın amacı, üniversite öğrencilerinin parayla olan ilişkilerini; yalnızca ailelerindeki finansal sosyalleşme düzeyleri açısından değil, aynı zamanda demografik ve sosyo-ekonomik özellikleri açısından açıkça ortaya koymaktır. Bunun dışında, üniversite öğrencilerinin aile finansal sosyalleşme düzeylerini ölçmek için "finansal deneyim ve öğrenme" ile "para yönetimi becerilerinden" oluşan iki boyutlu yeni bir ölçek geliştirilmiştir. Bu araştırma, ailede yaygın eğitimin geliştirilmesi yoluyla ebeveynler ve öğrenciler arasında olumlu finansal davranışlar yaratma olasılığının yüksek olması sebebiyle önem arz etmektedir. Ayrıca, araştırma, eğitim kurumlarında, özellikle para tutumları ve finansal sosyalleşme konularında yeni finansal eğitim programları oluşturmak için büyük olasılıkla faydalı olacaktır. Neden-sonuç ilişkilerine gelince, öğrencilerin finansal deneyimleri ve öğrenmeleri arttıkça birikim ve finansal okuryazarlık konusundaki endişelerinin azaldığı tespit edilmiştir. Bu sonuca ilave olarak, öğrencilerin para yönetimi becerilerinin artmasıyla dikkatli ve sorumlu tutumlarının arttığı görülmüştür. Son olarak, aile finansal sosyalleşmesi ile demografik ve sosyo-ekonomik özellikler arasında ve ayrıca parasal tutumlar ile demografik ve sosyo-ekonomik özellikler arasında önemli farklılıklar tespit edilmiştir.

Anahtar Kelimeler: Aile Finansal Sosyalleşme, Para Yönetimi Becerileri, Finansal Deneyim, Finansal Okuryazarlık, Para Tutumu.

JEL Sinıflandırma Kodları: G40, D10, D14, G53, Z13.

\footnotetext{
For the study, ethics committee approval no 2014/08-13 dated 05.06.2020 is taken from the Ethics Committee of Zonguldak Bülent Ecevit University.

1 (D) Zonguldak Bülent Ecevit University, School of Applied Sciences, Department of Finance and Banking, bilgehan.kubilay@beun.edu.tr

2 (D) Pamukkale University, Bekilli Vocational School, Foreign Trade Department, ozgur.tuncel@ hotmail.com

Makale Geliş Tarihi / Received : :24.10.2020

Makale Kabul Tarihi / Accepted $\quad: 11.04 .2021$ 


\section{GENIŞLETILMIŞ ÖZET}

\section{Amaç ve Kapsam:}

Bu araştırmanın üç temel amacı bulunmaktadır: İlk amaç, üniversite öğrencilerinin aile içindeki finansal sosyalleşme düzeyleri ile para tutumları arasındaki neden-sonuç ilişkilerini irdelemektir. İkinci amaç, üniversite öğrencilerinin aile içindeki finansal sosyalleşme boyutlarının ve para tutumlarının demografik ve sosyo-ekonomik özellikler açısından önemli ölçüde farklılaşıp farklılaşmadığını tespit etmektir. Son amaç ise öğrencilerin aile içindeki finansal sosyalleşme düzeylerinin ve para tutumlarının baskın boyutlarını ortaya koymaktır.

\section{Yöntem:}

Çalışma alanının tamamı Zonguldak Bülent Ecevit Üniversitesi Uygulamalı Bilimler Yüksekokulu / Bankacılık ve Finans Bölümünde öğrenim gören 198 lisans öğrencisini kapsadığından dolayı tam sayım yöntemi uygulanmıştır. Başka bir deyişle; araştırma, sonlu ve küçük hacimli bir evrene uygulandığı için toplam nüfus incelenmiştir. Ayrıca, anket geri dönüş oranının \% 59.09 (117 öğrenci) olduğu görülmüştür. Diğer üniversiteler, bölümler ve sektörler; bu araştırma kapsamına dâhil edilmemiştir. Veri toplama tekniklerinden yalnızca çevrimiçi anket kullanılmıştır. Anket, üç ana değişkene yönelik tasarlanmıştır: Öğrencilerin aile içindeki finansal sosyalleşme düzeylerinin belirlenmesi için iki faktörden \{finansal deneyim ve öğrenme; para yönetimi becerileri $\}$ ve on dört ifadeden oluşan 5'li Likert tipi $\{1=$ Asla, $2=$ Nadiren, $3=$ Bazen, $4=$ Genellikle, $5=$ Her zaman $\}$ bir ölçek geliştirilmiştir. Bu ölçeğin geliştirilmesinde, öncelikle literatürdeki çeşitli kaynaklarda (Kowalczyk and Chudzian, 2015; Cwynar, Cwynar, Baryla-Matejczuk and Betancort, 2019; Lee and Mortimer 2009; Kim and Chatterjee, 2013; Glenn, 2018) yer alan birçok ifade taranmış ve sonrasında faktör analizi yapılmıştır. Öğrencilerin para tutumundaki baskın boyutları ölçebilmek için beş faktör ve yirmi sekiz ifadeden oluşan "para tutumları ölçeği” Lay ve Furnham'ın (2018) çalışmasından uyarlanmıştır. Yapılan açıklayıcı faktör analizi sonucunda orijinal ölçek; dört faktörden \{birikim ve finansal okuryazarlık ile ilgili endişeler, dikkatli ve sorumlu, güç ve statü, kazanım ve başarı $\}$ ve yirmi yedi ifadeden oluşan 5'li Likert tipi $\{1=$ Kesinlikle katılmıyorum, 2= Katılmıorum, 3= Kararsızım, 4= Katılıyorum 5= Kesinlikle katılıyorum $\}$ bir ölçeğe dönüştürülmüştür. Son olarak da demografik ve sosyo-ekonomik faktörler belirlenmiştir. Araştırma değişkenlerine ve alt boyutlarına yönelik tanımlayıcı \{frekans, yüzde, ortalama, toplam puan ortalaması, standart sapma\} ve yorumlayıcı \{Pearson korelasyon, çoklu doğrusal regresyon ve tek yönlü çok değişkenli varyans analizleri (MANOVA)\} istatistiki analizler uygulanmıştır.

\section{Bulgular:}

Araştırma hipotezlerine ilişkin kayda değer bulgulara ulaşılmıştır: İlişkisel ve nedensel hipotezlerden H1(a), H1(b); H2(a), H2(b) ve H3(a), H3(b) kabul edilirken; H1(c), H1(d); H2(c), H2(d) ve H3(c), H3(d) ise reddedilmiştir. Farkl1lık hipotezlerinden H4.2., H4.4., H4.7., H4.9. ve H5.1., H5.2., H5.4., H5.6 ve H5.9. kabul edilirken; H4.1. H4.3. H4.5. H4.6., H4.8 ve H5.3., H5.5., H5.7., H5.8. ise reddedilmiştir.

\section{Sonuç ve Tartışma:}

Üniversite öğrencilerinin aile içindeki finansal sosyalleşme düzeyleri ile para tutumları arasındaki neden-sonuç ilişkileri incelendiğinde, öğrencilerin finansal deneyimleri ve öğrenmeleri arttıkça; birikim ve finansal okuryazarlık konusundaki endişelerinin azaldığı tespit edilmiştir. Bu durumda, üniversite öğrencilerinin çoğunun, ebeveynlerinin, finansal işlerle ne ölçüde başa çıkabileceklerinin farkında olmalarının ve ayrıca ebeveynlerinin finansal konular hakkında deneyim ve bilgi birikimine sahip olmalarının; öğrencilerin finansal konularda kendilerini cahil hissetmeye ve parasız kalmaya yönelik endişelerini azalttığı söylenebilir. Ayrıca, öğrencilerin para yönetimi becerilerinin artması ile paraya yönelik dikkatli ve sorumlu tutumlarının arttığı görülmüştür. Bu durum, üniversite öğrencilerinin çoğunun, ebeveynlerinin finansal sorunları yönetme, gelirlerine göre harcama yapma, düzenli olarak para biriktirme, tasarruf planı yapma ve zamanında ödeme yapma becerilerine sahip olmalarının; öğrencilerin kendilerini güvende hissetmek ve başkaları tarafından kontrol edilmemek için para biriktirmelerini ve yatırım yapmalarını arttırdığı şeklinde yorumlanabilir. Diğer boyutlar yönünden ise anlamlı etkiler bulunamamıştır. Üniversite öğrencilerinin aile içindeki finansal sosyalleşme düzeylerinin demografik ve sosyo-ekonomik faktörlerden "yaş, annenin eğitim durumu, babanın çalışma durumu ve ailenin aylık geliri” yönünden anlamlı farklılıklar gösterdiği saptanmıştır. Annelerinin eğitim durumları yükseldikçe; öğrencilerin "finansal deneyim ve öğrenmeleri” ve "para yönetimi becerilerinin" arttığı bulunmuştur. Ailelerinin aylık geliri düştükçe, öğrencilerin finansal deneyim ve öğrenme ve para yönetimi becerilerinin azaldığı görülmüştür. Üniversite öğrencilerinin para tutumlarının demografik ve sosyo-ekonomik faktörlerden "cinsiyet, yaş, annenin eğitim durumu, annenin çalışma durumu ve ailenin aylık geliri” yönünden anlamlı farklılıklar gösterdiği tespit edilmiştir. Üniversite öğrencilerinin paraya yönelik kazanım ve başarı tutumu, annelerinin çalışmasıyla birlikte arttığı görülmüştür. Ayrıca, öğrencilerin ailelerinin aylık geliri düştükçe; paraya yönelik birikim ve finansal okuryazarlık konusundaki endişelerinin arttı̆̆ 1 sonucuna ulaşılmıştır. Üniversite öğrencilerinin aile içindeki finansal sosyalleşme düzeylerine gelince, öğrenciler tarafindan hem finansal deneyim ve öğrenme hem de para yönetimi becerilerinin yüksek düzeyde algılandığ 1 tespit edilmiştir. Bununla birlikte, öğrencilerin finansal deneyim ve öğrenmelerine göre, para yönetimi becerilerinin biraz daha yüksek olduğu anlaşılmıştır. Son olarak, üniversite öğrencilerinin para tutumlarındaki baskın boyutlar incelendiğinde; "dikkatli ve sorumlu" boyutun yüksek düzeyde, "birikim ve finansal okuryazarlık endişesi" ve "kazanım ve başarı" boyutlarının orta düzeyde ve "güç ve statü" boyutunun ise öğrenciler tarafından en düşük düzeyde algılandığı görülmüştür. 


\section{INTRODUCTION}

It is a well-known fact by everyone that money is crucial. We think, discuss and even dream about it. It consumes a lot of psychological and emotional energy. "What is the meaning of money for people? How does money affect human behaviour? " These general questions are put vital questions about money forward that social scientists must answer (Mitchell and Mickel, 1999: 568).

Money is one of both common and "exceptional" things. Economically, money is universal as means of exchange and a unit of account, on the other hand psychologically, it is not universal; it is emotional and a social resource for organizing interpersonal relationships (Gasiorowska and Helka, 2012: 20).

Money has materialist and symbolic meanings. There is a deep relationship between the materialistic tendencies of people and the symbolic meanings they give to money. It is defined as "materialistic tendencies" that people give priority and value to money and material assets in their lives. However, seeing money by people as a source of anxiety and security, a symbol of status and success for an uncertain future is expressed as "symbolic meanings" (Doğan and Torlak, 2014). Money attitude is about the person's perception of money. The attitude of the person about money determines the behaviour. The attitude towards money is multifaceted. People develop an attitude, based on the situations and experiences they have encountered throughout their lives (Taneja, 2012: 3).

Consumer socialization and financial socialization are sub-components of economic socialization. Financial socialization is more comprehensive than consumer socialization. Financial socialization is the process of acquiring and developing knowledge, skills, norms, standards and attitudes, including understanding the basic financial terms and concepts (investment, savings, bank transactions, insurance, credit card use, home and health insurance etc.) in money and money management. In this regard, financial literacy is a product of financial socialization. Learning styles about financial issues of young people vary one to another. Young people consciously or unconsciously learn strategies on financial issues from adults who play a key role in their lives. They do this by involving financial discussions within the family or by observing how families handle financial issues. Therefore, parents are the primary representatives of financial socialization. Other factors that contribute to the knowledge of young people about money are the mass media and their conversations with their peers (Fulk and White, 2018: 2; Bowen, 2002; Danes, 1994).

As a matter of fact, financial socialization processes in families need to be included in personal finance research (Danes, 1994). According to Gudmunson and Danes (2011), ignoring of family socialization processes metaphorically resembles one-handed shoe tying which means an important component in financial socialization is missing.

\section{RESEARCH PROBLEM}

Family financial socialization commences in early childhood. Accordingly, it is important that parents provide guidance to children on financial management. Parents need to have sufficient capacity (knowledge, ability, attitude, behaviour) in terms of financial information in order to educate their children on issues, such as using credit card, borrowing, and lifetime savings until they earn their own incomes (Garrison, 2010; Dilworth, Chenoweth and Engelbrecht, 2000; Ramirez and Torres, 2014). In any way, families shape children's money attitudes. Implicit or explicit messages of families about money for children are called "scripts". These messages conveyed in childhood permanently determine the attitudes and thoughts of adults towards money (Furnham, Stumm and Milner, 2014). Economic knowledge is not only through formal education; it is also learned through experience. In this respect, the economic conditions in which the child has grown, financial experiences, behaviours and beliefs of families in the economic socialization of children should be included in money attitude research (Furnham and Milner, 2017; Kowalczyk and Chudzian, 2015: 11).

According to Stumm, Fenton-O'Creevy and Furnham (2013), financial experiences arise from individuals' psychological and socio-economic differences. "Why do some people suffer financially while others do not?" In order to understand this, it is necessary to take into account the differences in people's attitudes towards money, financial skill differences as well as financial conditions created by people. In addition, the financial experiences and trainings that people have acquired from the family determine their attitudes towards money (Furnham and Milner, 2017). Knowing the factors that affect people's money attitude can assist them in shaping economically desirable attitudes. Developing these attitudes affects economic socialization and therewithal economic socialization also affects financial behaviour (Kowalczyk and Chudzian, 2015). 
When all is said and done, the problem of this research is to what extent dimensions of family financial socialization which consist of financial experience and learning and money management skills of university students have simultaneous significant effects on their money attitudes.

\section{PURPOSE AND IMPORTANCE OF RESEARCH}

The purpose of this research is to scrutinize the cause and effect relationships between family financial socialization levels and money attitudes of university students. And therewithal, the research aims to manifest that family financial socialization dimensions and money attitudes of the university students whether differ significantly in terms of demographic and socio-economic characteristics. Finally, family financial socialization levels and dominant dimensions of money attitude of students are examined.

In accordance with examined literature during the research, there are no encounter concurrent studies either local or foreign about relationships between family financial socialization levels and money attitudes of university students. Furthermore, in order to measure family financial socialization levels of university students, a new twodimensional scale, which is composed of financial experience \& learning and money management skills, has been developed. Thus, this research draws attention to the gap in the literature.

It is anticipated that the results obtained from this research most likely to be effective for families, students and educational institutions, and also assist in the creation of education programs. From an economic standpoint, university students will be likely to aware of the extent to which they correlate money with power and status, achievement and success, mindful and responsible and worries about savings and financial literacy and also they attach importance to financial experience and learning and money management skills. Moreover, parents will be likely to aware of the extent to which they are able to shape and develop their children's money beliefs and also they educate them through providing right information about financial issues and managing finances in order to bring positive financial behaviours in their children.

\section{LITERATURE REVIEW}

The literature has been scrutinized in two aspects as money attitude and family financial socialization.

\subsection{Money Attitude Concept}

Many scales have been developed regarding money attitude. Known one of the oldest and most widely used scale belongs to Yamauchi and Templer (1982). The Money Attitude Scale (MAS) of Yamauchi and Templer consisted of four factors: Anxiety, Power-Prestige, Retention-time and Distrust. Furnham (1984), developed a six-factor "Money Beliefs and Behaviours Scale". Tang (1992), developed a six-factor "Money Ethics Scale" (good, evil, achievement, respect and freedom, budget). Tang and Chiu (2003), developed a "The Love of Money Scale" with four factors (Importance, success, motivator and rich). Klontz, Britt and Mentzer (2011), created a four-factor money belief scale: Money avoidance, money worship, money status, money vigilance.

Lay and Furnham (2018), developed a new modern money attitude scale (achievement and success, power and status, mindful and responsible, savings concerns, financial literacy worries) by adding the financial literacy level to the literature. Particularly, financial literacy is the ability to understand how money works in the world. Financial literacy requires understanding how people earn money, how they manage it, how they invest, as well as why and when they donate to others. Essentially, it refers to the knowledge and skills that enable the person to make informed and effective decisions in the use of financial resources. In fact, people are aware of the extent to which they are literate about money (Lay and Furnham, 2018: 4).

Mitchell and Mickel (1999: 568), propose that perspectives which present emotional and social meanings of money are existed in psychology and sociology. For this reason, money should be examined in terms of sociology and psychology to find out what it means to people. It is known that money beliefs and values vary from person to person. There are many studies in the literature that inspect money attitudes in terms of psychological and sociological.

In a study by Moreno, Salcedo, Rebellon and Anzelin (2018), money is not seen as a dominant factor in social relations for university students. The meaning that students add to money is romantic, and the real use of money for them is for subsistence and entertainment. According to Zhou, Vohs and Baumeister (2009), which deals with 
money socially and psychologically, money replaces social acceptance in providing the convenience to benefit from the social system. In other words, money is a social resource. Money gives people a sense of trust because money plays an important role in solving problems and meeting needs. With the self-confidence of money, people need less approval from others. Researchers, who argue whether money is related to social exclusion and physical pain, found that social rejection and physical pain cause an increase in the desire for money. On the other hand, Juneman, Meinarno and Wahyu (2012), argue that low self-esteem may create a sense of not deserving money or reject money to protect people's self-esteem.

There are also studies on those who have emotional problems about money (those with money pathology) (Furnham et al., 2014; Klontz, Britt, Archuleta and Klontz, 2012). Furnham (2019), investigated the relationship between personality disorder and money attitude, Roberts and Cesar (1999), examined the relationship between compulsive buying behaviour of young adults and money attitude. Dowling, Corney and Hoiles (2009), suggest that there is a relationship between money attitudes (materialism, evaluation-comparison and anxiety) and financial problems in their research. In the research, it was determined that the level of financial problems of those with high anxiety attitude towards money and high attitude of evaluation-comparison is high. Roberts and Jones (2001), researched the effect of money attitude and credit card use on compulsive purchasing in their research on students in America. In the study, the question of which money attitude helps to understand compulsive buying, it was found that those with high anxiety levels showed more compulsive buying behaviour. Klontz, Bivens, Klontz, Wada and Kahler (2008: 296), define disorder money behaviours as mismatched patterns of financial belief. Symptoms of money disorder are seen as excessive anxiety or despair about the financial situation, excessive debt, bankruptcy, money conflict with family or other people, excessive stacking, financial dependency or taking excessive financial risks.

\subsection{Concept of Family Financial Socialization}

Social norms, attitudes towards spending, positive childhood experiences, financial knowledge and experiences of families are effective in determining financial management (Hilgert, Hogart and Beverly, 2003).

Since financial socialization is different in every family, these gaps are tried to be filled through education. Fulk and White (2018), addressed that in financial socialization; not only formal education but also family education was effective in children's financial behaviour. Families use a variety of ways and methods to educate their children about money. Antoni, Rootman and Struwig (2019), investigated financial socialization techniques used by families that had an impact on students' financial behaviour. Accordingly, there are seven financial socialization techniques that families use: Financial confidentiality, financial conflict, financial education, modelling financial behaviour, monitoring financial behaviour, strengthening financial behaviour, and parent relationships. As a result of the research, it was revealed that the most important financial technique affecting children's financial behaviour was financial education and financial monitoring.

If there is a connection between financial information and financial behaviour, it is also important where families get this financial information. Families learn this information from a variety of sources, including personal financial experiences, family, friends, and the media. In the research conducted by Hilgert et al., (2003) it was revealed that the most effective factor among these sources is personal financial experience.

Families create a role model by directly or indirectly influencing children's financial behaviour through their own experiences. Families influence children's financial decision-making processes and habits, how they use and obtain money. Children who observe and experience the relationships of families with financial institutions will determine their financial behaviour and attitudes while managing their own money in the future. For this reason, families also need to improve their financial capacity, such as financial knowledge, ability, attitude and behaviour (Ramirez and Torres, 2014).

Children's financial socialization experiences are related to the acquisition of financial assets in adulthood. It was determined that children who had an accumulation account in childhood and whose expenses were monitored by their families had financial assets in adulthood and were less anxious about financial matters, and were better at managing financial matters. It was revealed that those who received pocket money from their parents were more responsible in managing financial matters and were less anxious about financial matters (Kim and Chatterjee, 2013). 
Solheim, Zuiker and Levchenko (2011), investigated the story of what the university student learned from their families in terms of finance through qualitative analysis. It was revealed that the most common concept that students learned from their families in their childhood was savings. The students learned the saving behaviour by observing the saving behaviour of the families. Students who observed that their families could manage their money and save money learned the importance of saving and money management from their families.

Bowen (2002), investigated what young people know about money other than spending money, how familiar they are with basic financial terms and concepts related to money matters likely to encounter as young adults, as well as whether there is a relationship between what young people know about money and what families know about money. In the research, a significant relationship was found between the information of the young people and parents about money.

\section{RESEARCH METHODOLOGY}

\subsection{Research Design and Data Collection Techniques}

The cause and effect relationships as well as correlations and differences between variables were thoroughly investigated in this quantitative research design. As far as data collection techniques were concerned, survey was merely used. Data were obtained by means of conducting an online survey in google forms. According to the questionnaire, three major divisions consisting of statements in the demographic \& socio-economic characteristics, family financial socialization and money attitudes were determined:

Demographic and Socio-Economic Variables: Descriptive profile of university students was composed of (1) gender, (2) age, (3) settlement, (4) mother's educational status, (5) father's educational status, (6) mother's working condition, (7) father's working condition, (8) number of people in the family and (9) monthly family income.

Family Financial Socialization Variable: With a view to measuring of university students' levels of family financial socialization, a new questionnaire has been developed by means of obtaining statements about family financial socialization from various sources: (Kowalczyk and Chudzian, 2015; Cwynar, Cwynar, BarylaMatejczuk and Betancort, 2019; Lee and Mortimer 2009; Kim and Chatterjee, 2013; Glenn, 2018). After the verification of factor analysis, the questionnaire was composed of two family financial socialization dimensions which were financial experience \& learning (FEL) and money management skills (MMS). As regards the questionnaire statements, 14 items were determined. Furthermore, a five-point Likert type scale $(1=$ Never, 2=Rarely, 3= Sometimes, 4=Usually and 5=Always) was used to determine frequency levels on statements.

Money Attitude Variable: "Money attitudes scale" consisting of five factors and twenty eight statements was adapted from the study of Lay and Furnham (2018) so that it could measure university students' dominant dimensions of money attitude. The factors in the original scale were classified: Achievement and Success, Power and Status, Mindful and Responsible, Savings Concerns, Financial Literacy Worries. Although, the original scale had five factors; a four-factor model with 27 statements which was composed of Worries about Savings and Financial Literacy (WSFL), Mindful and Responsible (MS), Power and Status (PS) and Achievement and Success $(A S)$ was obtained, after exploratory factor analysis was performed in this research. Moreover, a five-point Likert type scale (1=Strongly Disagree, 2=Disagree, 3=Undecided, 4=Agree and 5=Strongly Agree) was used to determine levels of participation on statements.

\subsection{Data Analysis Methods}

It was decided to use parametric methods, inasmuch as normal distribution and sample size conditions were met. At the same time, internal consistency and validity of statements and dimensions in the research were confirmed by reliability and factor analysis. After these crucial preliminary findings; descriptive statistics and inferential statistics commenced to be used in this research.

Descriptive statistics (Mean, Total Score, Total Score Mean, Standard Deviation, Frequency and Percentage) were used to analyze data on demographic and socio-economic characteristics, family financial socialization and money attitudes variables.

Scale options and score ranges for the research variables are presented in Table 1. 
Süleyman Demirel Üniversitesi Vizyoner Dergisi, Yıl: 2021, Cilt: 12, Sayı: 30, 393-416.

Süleyman Demirel University Visionary Journal, Year: 2021, Volume: 12, No: 30, 393-416.

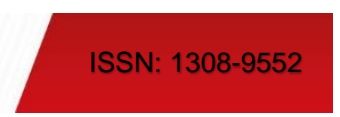

Table 1. Scale Options and Score Ranges for the Statements and Dimensions

\begin{tabular}{cccccccc}
\hline $\begin{array}{c}\text { Group } \\
\text { Numbers }\end{array}$ & $\begin{array}{c}\text { Score } \\
\text { Ranges-1 }\end{array}$ & Midpoint-1 & $\begin{array}{c}\text { Score } \\
\text { Ranges-2 }\end{array}$ & Midpoint-2 & $\begin{array}{c}\text { Frequency } \\
\text { Levels }\end{array}$ & $\begin{array}{c}\text { Participation } \\
\text { Levels }\end{array}$ & $\begin{array}{c}\text { Category } \\
\text { Labels }\end{array}$ \\
\hline 1 & {$[1-1,80)$} & 1,40 & {$[117-210,6)$} & 163,8 & Never & Strongly Disagree & Very Low \\
2 & {$[1,80-2,60)$} & 2,20 & {$[210,6-304,2)$} & 257,4 & Rarely & Disagree & Low \\
3 & {$[2,60-3,40)$} & 3,00 & {$[304,2-397,8)$} & 351 & Sometimes & Undecided & Moderate \\
4 & {$[3,40-4,20)$} & 3,80 & {$[397,8-491,4)$} & 444,6 & Usually & Agree & High \\
5 & {$[4,20-5]$} & 4,60 & {$[491,4-585]$} & 538,2 & Always & Strongly Agree & Very High \\
\hline
\end{tabular}

$117 \min \leq \mathrm{TS} \leq 585 \max ; 117 \min \leq \mathrm{TSM} \leq 585 \max ; 1 \min \leq \mathrm{M} \leq 5 \max \quad$ Coefficient of group (SR1)= 0,80; Coefficient of group (SR2)= 93,6

As seen in Table 1, according to the total score, the highest score of 585 and the lowest of 117 points are possible to obtain from every one statement as there is not an empty statement. As regards total score mean, the highest score of 585 and the lowest of 117 points are possible to obtain from every one dimension. Finally, the lowest score of 1 and the highest of 5 points are possible to get from every one statement and dimension about mean.

Inferential statistics were used to analyze research hypotheses. As a matter of fact, Pearson correlation analysis for Hypothesis 1-2, multiple linear regression analysis for Hypothesis 3 and one-way MANOVA analysis for Hypothesis 4-5 were operated in this research.

\subsection{Research Universe}

Since the entire study area included 198 undergraduate students studying at the Zonguldak Bülent Ecevit University School of Applied Sciences / Department of Banking and Finance, total count (census) method was applied. On account of the research was applied to a finite and small volume universe, the total population was examined. Besides, it was observed that the survey return rate was \% 59, 09 (117 students) of these 198 students.

\subsection{Research Questions}

1) What are the family financial socialization levels of university students?

2) What are the dominant money attitudes of university students?

3) Is there a statistically significant relationship between university students' family financial socialization dimensions and money attitudes?

4) Do the family financial socialization dimensions of the university students differ significantly, based on their demographic and socio-economic characteristics?

5) Do the money attitudes of the university students differ significantly, based on their demographic and socioeconomic characteristics?

\subsection{Research Hypotheses}

H1: There is a significant relationship between university students' "financial experience and learning in the family financial socialization" and "money attitudes" $\{$ (a) Worries about savings and financial literacy (b) mindful and responsible (c) power and status (d) achievement and success $\} \mathrm{H1}=\{\mathrm{H} 1$ (a), H1(b), H1(c), H1(d) $\}$

$\mathrm{H} 2$ : There is a significant relationship between university students' "money management skills in the family financial socialization" and "money attitudes" (a) Worries about savings and financial literacy, (b) mindful and responsible, (c) power and status, (d) achievement and success $\} \mathrm{H} 2=\{\mathrm{H} 2(\mathrm{a}), \mathrm{H} 2(\mathrm{~b}), \mathrm{H} 2$ (c), $\mathrm{H} 2$ (d) $\}$

H3: University students' "financial experience and learning" and "money management skills" have simultaneous significant effects on money attitudes $\{$ (a) Worries about savings and financial literacy, (b) mindful and responsible, (c) power and status, (d) achievement and success $\} \mathrm{H} 3=\{\mathrm{H} 3(\mathrm{a}), \mathrm{H} 3(\mathrm{~b}), \mathrm{H} 3(\mathrm{c}), \mathrm{H} 3(\mathrm{~d})\}$

H4: "Financial experience and learning" and "money management skills" of the university students differ significantly, based on their demographic and socio-economic characteristics. (1-2-3-4-5-6-7-8-9 factors) H4= $\{\mathrm{H} 4.1, \mathrm{H} 4.2$, H4.3, H4.4, H4.5, H4.6, H4.7, H4.8, H4.9\}

H5: Money attitudes of the university students differ significantly, based on their demographic and socio-economic characteristics. (1-2-3-4-5-6-7-8-9 factors) $\mathrm{H} 5=\{\mathrm{H} 5.1, \mathrm{H} 5.2, \mathrm{H} 5.3, \mathrm{H} 5.4, \mathrm{H} 5.5, \mathrm{H} 5.6, \mathrm{H} 5.7, \mathrm{H} 5.8, \mathrm{H} 5.9\}$ 


\subsection{Research Model}

Two-dimensional family financial socialization variable and four-dimensional money attitude variable are indicated in research model.

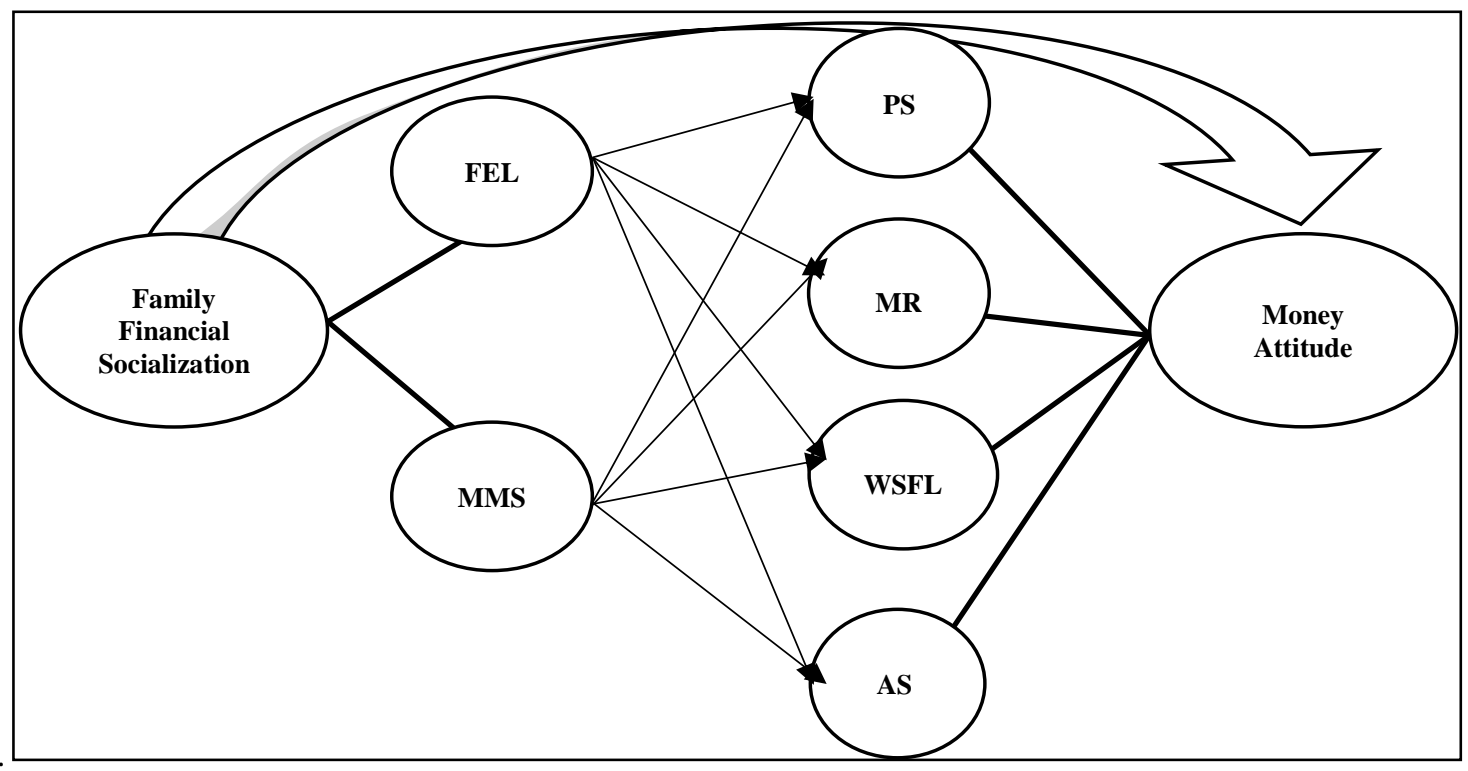

Figure 1. View of the Research Model

Figure 1 shows that effects of financial experience \& learning (FEL) and money management skills (MMS) dimensions of family financial socialization on money attitudes which consist of worries about savings \& financial literacy (WSFL), mindful and responsible (MR), power and status (PS) and achievement and success (AS) dimensions.

\subsection{Explanations for the Dimensions of Scale Structure}

As seen in model, there are two major variables and six dimensions (factors) in this research. Major variables are declared in literature review; on the other hand both two-dimensional (two-factor) structure of family financial socialization scale and four-dimensional (four-factor) structure of money attitudes scale are explained as follows:

A new scale of family financial socialization consists of two dimensions: Financial experience \& learning and money management skills.

Financial Experience and Learning: How financial issues are handled or evaluated within the family, the functions of families as a guide and role model in transferring financial information to children, communications with children in financial matters are both conscious and unconscious messages conveyed to children. In this respect, visiting their families' workplaces and observing financial behaviours, satisfying financial curiosity, learning how to be a smart consumer and how to use credit card by means of their parents shape and develop children's financial experiences and learning.

Money Management Skills: Children first learn about money management from their families. For this reason, how families attach importance to financial issues and manage finances, such as regularly saving money, making a savings plan, making payments on time, spending by income, setting a budget, encouraging correct financial behaviour and acting by basic financial principles characterize children's ability with money management.

Original money attitudes scale has five-factor structure; however a four-factor model has been detected for this research. These attitudes are adapted from the study of Lay and Furnham (2018: 2):

Worries about Savings and Financial Literacy: The motto of this dimension can be determined as worries about money are due to perceptual scarcity and understanding. Individuals with savings worries consider that not only having scarcely enough money for savings but also running out of money. Unless money is enough, it is a root 
cause of stress. And therewithal, finance is related to anxiety and depression. People with financial literacy worries feel themselves ignorant, with regard to financial matters. Inasmuch as they have difficulty understanding of financial issues, they are worried. As a matter of fact, they are both embarrassed and anxious to talk about money issues and personal finances with others.

Mindful and Responsible: The motto of this dimension can be declared as money acts like a protective shield around the changes in life. Many people think about saving and investing money for feeling safe. Operating money, people can buy what they really need, such as home and healthcare. Money also makes people feel that they are not owed to people who want to control them. People with these tendencies make savings by budgeting; they are not fined by paying their bills on time. These people are proud of themselves as they are responsible for money.

Power and Status: The motto of this dimension can be expressed as money talks and focuses on others for showing off and being respected. According to those who see money as a symbol of power and status, money refers to a situation where people struggle to earn and are happy to show it when they get the money. Money is the major source of social status and social power. People respect those who have reasonable money. People like being respected when they show their wealth.

Achievement and Success: The motto of this dimension can be described as the amount of money is a key of success in life. All in all, people with this attitude mostly focus on themselves and obtain a lot of money to feel a sense of accomplishment.

\subsection{Ethical Statements}

Before commencing the research application, written approval was received on 05.06.2020 from the Ethics Committee of Zonguldak Bülent Ecevit University with the Senate Decision numbered 2014 / 08-13. Afterwards, for conducting a survey to students, it was reported to Directorate of the School of Applied Sciences of the University, which affiliated with the Council of Higher Education, and also verbal approval was received from the institution. The students were informed about the purpose of the study, that the data obtained during the research could not be used for any other purpose than the research, that their names could not be included in the research findings, and that their participation in the study was a voluntary basis. In the line with met ethic conditions, the research questionnaire was applied to the university students between 21.07.2020 to 06.08.2020.

\section{RESEARCH FINDINGS}

\subsection{Factor and Reliability Analyses}

Factor and reliability analyses are preliminary examinations of research data so that it can confirm whether to have validity and internal consistency. In this way, factor and reliability tests of family financial socialization and money attitudes are performed as follows:

As shown in table 2, data are analyzed by principal component method. Sampling adequacy is verified for factor analysis, on the grounds that $\mathrm{KMO}$ value $(\mathrm{KMO}=0,880>0,50)$ is higher than 0,50 . In addition to this, Bartlett's test $(\mathrm{p}=0,000<0,01)$ is significant at the $\% 1$ level, supporting the factor ability of the correlation matrix. As a consequence, preliminary condition for the feasibility of factor analysis is realized.

Two factors, of which eigenvalues (FEL(e)=6,751 >1; MMS(e)=1,264>1) are over 1, are detected. Factor loadings of scale are found between 0,790 max and 0,549 min. Two factor statements are extracted from the scale inasmuch as one factor loading are less than 0,40, another is cross loading. Furthermore, financial experience and learning (FEL) and money management skills (MMS) factors account for \%48,221 and \%9,030 of family financial socialization scale respectively.

With a view to testing of internal consistency of factors, Cronbach's alpha value is used. In this context, reliability analysis shows that family financial socialization and its dimensions of financial experience \& learning and money management skills have considerable internal consistency by $\% 91, \% 89,3$ and \%80,1, respectively.

After all is said and done, two-factor structure of scale consisting of fourteen statements (FEL: 1-8 and MMS: 914) can measure university students' family financial socialization by $\% 57,251$. 
Table 2. Factor and Reliability Analyses of Family Financial Socialization Scale

\begin{tabular}{|c|c|c|c|}
\hline Statements & Factor Loadings & $\%$ of $\mathrm{V}$ & $\alpha$ \\
\hline 1. My parents have been taught me how to be a smart consumer since my childhood. & 0,751 & \multirow{8}{*}{$\% 48,221$} & \multirow{8}{*}{$\% 89,3$} \\
\hline 2. During my childhood, I used to visit my parents' workplaces. & 0,746 & & \\
\hline 3. My parents would teach me how to properly use my credit card before college. & 0,744 & & \\
\hline 4. I learned financial issues under the guidance of my parents in my childhood. & 0,715 & & \\
\hline $\begin{array}{l}\text { 5. I learned financial matters from observing my parents' money management in my } \\
\text { childhood. }\end{array}$ & 0,682 & & \\
\hline 6. Money has been a source of conflict and stress in our family. & 0,635 & & \\
\hline $\begin{array}{l}\text { 7. My parents have been a positive role model for me about in financial management } \\
\text { during my childhood. }\end{array}$ & 0,620 & & \\
\hline $\begin{array}{l}\text { 8. My parents kept me informed of whatever I was curious about financial issues in my } \\
\text { childhood. }\end{array}$ & 0,595 & & \\
\hline 9. My parents pay their bills on time. & 0,790 & \multirow{6}{*}{$\% 9,030$} & \multirow{6}{*}{$\% 80,1$} \\
\hline 10. My parents prefer to put aside some money each month for the future. & 0,697 & & \\
\hline 11. My parents care about financial matters. & 0,695 & & \\
\hline 12. My parents spend by their income. & 0,694 & & \\
\hline 13. My parents used to talk clearly about finances with me during my childhood. & 0,570 & & \\
\hline 14. My parents used to encourage me to save money in my childhood. & 0,549 & & \\
\hline
\end{tabular}

* KMO: 0,880 * Barlett's test=\{Chi square: 907,218; df: 91; P value: 0,000$\}$ * Total variance explained: $\% 57,251$

Table 2 indicates the factors, statements, factor loadings, \% of variance and Cronbach's alpha values of family financial socialization scale.

As seen in table 3, data are analyzed by principal axis factor method. These data are feasible for factor analysis inasmuch as $\mathrm{KMO}$ value $(\mathrm{KMO}=0,813>0,50)$ and Bartlett's test $(\mathrm{p}=0,000<0,01)$ conditions are statistically met.

Four factors, of which eigenvalues (WSFL(e)=7,741>1; MR(e)=4,736>1; PS(e)=2,789 >1; AS(e)=1,790>1) are over 1, are observed. Factor loadings of scale are ascertained between 0,872 max and 0,401 min. One statement is extracted from the scale on the grounds that factor loading is less than 0,40. Moreover, worries about savings and financial literacy (WSFL), mindful and responsible (MR), power and status (PS), achievement and success (AS) factors account for $\% 28,670, \% 17,540, \% 10,328$ and $\% 6,628$ of money attitudes scale respectively.

As shown in table 3, Cronbach's alpha values are used to test internal consistencies of factors. In this respect, reliability analysis indicates that money attitude and its dimensions of WSFL, MR, PS and AS have notable internal consistencies by $\% 89, \% 90,9, \% 90,7, \% 86,9$ and $\% 84,5$ respectively.

When all is said and done, four-factor structure of scale consisting of twenty seven statements (WSFL: 1-10; MR: 11-16; PS: 17-21 and AS: 22-27) can measure university students' money attitudes by \%63,167.

Table 3. Factor and Reliability Analyses of Money Attitudes Scale

\begin{tabular}{ll}
\hline I Statements & Factor Loadings \\
\hline 1. I have a real fear of being broke. & 0,872 \\
2. I am continuously worried about how hardly any savings I have & 0,862 \\
3. I am really worried about whether my savings are sufficient. & 0,798 \\
4. The quantity of money which I have saved is never satisfactory. & 0,780 \\
5. Even considering my money worries me. & 0,710 \\
6. It appears that I will never have adequate money. & 0,648 \\
7. I feel worried and defensive when talking about my personal finances. & 0,647 \\
8. Relative to most people, I am much more concerned about money. & 0,626 \\
9. I feel stupid and ashamed whenever I talk about many money matters. & 0,475 \\
10. I don't really understand financial conversation and jargon. & 0,401 \\
\hline
\end{tabular}


Süleyman Demirel Üniversitesi Vizyoner Dergisi, Yıl: 2021, Cilt: 12, Sayı: 30, 393-416.

Süleyman Demirel University Visionary Journal, Year: 2021, Volume: 12, No: 30, 393-416.

\begin{tabular}{|c|c|c|c|c|}
\hline Statements & Factor Loadings & & $\%$ of $\mathrm{V}$ & $\alpha$ \\
\hline 11. I am good enough at budgeting & 0,863 & & \multirow{6}{*}{17,540} & \multirow{6}{*}{$\% 90,7$} \\
\hline 12. I am really proud of my ability to save money. & 0,858 & & & \\
\hline 13. I am much of a saver than an extravagant person. & 0,813 & & & \\
\hline 14. Saving money for the dark day is crucial to me. & 0,782 & & & \\
\hline 15. I follow closely of my money affairs. & 0,700 & & & \\
\hline 16. In order to avoid interest and penalties, I pay my bills immediately. & 0,656 & & & \\
\hline 17. I show off to people by the branded products which I have bought & 0,869 & & \multirow{5}{*}{10,328} & \multirow{5}{*}{$\% 86,9$} \\
\hline 18. With a view to persuading people to help me, I like using money. & 0,744 & & & \\
\hline 19. I am quite happy to let people know how much money I have. & 0,727 & & & \\
\hline 20. I enjoy buying expensive products to impress others. & 0,708 & & & \\
\hline 21. I am proud of my financial "victories" and I tell people about them. & 0,589 & & & \\
\hline 22. Being rich is a sign of great achievement. & & 0,809 & \multirow{6}{*}{6,628} & \multirow{6}{*}{$\% 84,5$} \\
\hline $\begin{array}{l}\text { 23. One of the best criterion of success in life is how much money } \\
\text { you've earned }\end{array}$ & & 0,803 & & \\
\hline 24. Earning a lot of money is one of the best achievements in life & & 0,771 & & \\
\hline $\begin{array}{l}\text { 25. Money is a really good measure of a person's life achievements and } \\
\text { success. }\end{array}$ & & 0,746 & & \\
\hline 26. Money really talks about your status in life. & & 0,515 & & \\
\hline 27. You need money to buy the good things in life. & & 0,421 & & \\
\hline
\end{tabular}

* KMO: 0,813 * Barlett's test= $\{$ Chi square: 2204,915; df: 351; P value: 0,000 $\}$ * Total variance explained: \%63,167

Factors, statements, factor loadings, $\%$ of variance and Cronbach's alpha $(\alpha)$ values of money attitudes scale are shown in table 3

\subsection{Demographic and Socio-Economic Findings}

Descriptive statistics of demographic and socio-economic characteristics are showed in table 4.

Table 4. Descriptive Statistics of Demographic and Socio-Economic Characteristics

\begin{tabular}{|c|c|c|c|c|c|c|c|}
\hline & Factors & $\mathbf{F}$ & $\%$ & & Factors & $\mathbf{F}$ & $\%$ \\
\hline \multirow{4}{*}{ Gender } & \multirow{2}{*}{ Female } & \multirow{2}{*}{79} & \multirow{2}{*}{67,5} & \multirow{4}{*}{$\begin{array}{c}\text { Mother's Educational } \\
\text { Status }\end{array}$} & Not any school graduate. & 3 & 2,6 \\
\hline & & & & & Primary school & 74 & 63,2 \\
\hline & \multirow{2}{*}{ Male } & \multirow{2}{*}{38} & \multirow{2}{*}{32,5} & & Middle School -High School & 34 & 29,1 \\
\hline & & & & & University & 6 & 5,1 \\
\hline \multirow{4}{*}{ Age } & $18-20$ & 32 & 27,4 & \multirow{4}{*}{$\begin{array}{c}\text { Father's Educational } \\
\text { Status }\end{array}$} & Not any school graduate. & - & - \\
\hline & $21-24$ & 78 & 66,7 & & Primary school & 56 & 47,8 \\
\hline & $25-28$ & 5 & 4,2 & & Middle School -High School & 58 & 49,6 \\
\hline & 29 and above & 2 & 1,7 & & University & 3 & 2,6 \\
\hline \multirow{3}{*}{ Settlement } & City Center & 48 & 41 & \multirow{3}{*}{$\begin{array}{l}\text { Mother's Working } \\
\text { Condition }\end{array}$} & Working & 26 & 22,2 \\
\hline & County Center & 49 & 41,9 & & Not working in any job & 90 & 76,9 \\
\hline & Village & 20 & 17,1 & & Retired & 1 & 0,9 \\
\hline \multirow{3}{*}{$\begin{array}{l}\text { Number of } \\
\text { People in } \\
\text { the Family }\end{array}$} & $1-2$ & 5 & 4,3 & \multirow{3}{*}{$\begin{array}{l}\text { Father's Working } \\
\text { Condition }\end{array}$} & Working & 80 & 68,4 \\
\hline & $3-4$ & 59 & 50,4 & & Not working in any job & 14 & 11,9 \\
\hline & 5 and above & 53 & 45,3 & & Retired & 23 & 19,7 \\
\hline \multirow{3}{*}{$\begin{array}{l}\text { Monthly } \\
\text { Family } \\
\text { Income }\end{array}$} & $\begin{array}{l}\text { Below the Minimum Wage } \\
\text { Level }\end{array}$ & 11 & 9,4 & \multirow[t]{3}{*}{ Total } & & 117 & 100 \\
\hline & Minimum Wage Level & 52 & 44,4 & & & & \\
\hline & $\begin{array}{l}\text { Above the Minimum Wage } \\
\text { Level }\end{array}$ & 54 & 46,2 & & & & \\
\hline
\end{tabular}


As shown in table 4, demographic and socio economic profiles of university students mostly consist of female $(\% 67,5)$, age range of $21-24(\% 66,7)$, settlement in country center $(\% 41,9)$, mother's educational status: Primary school $(\% 63,2)$, father's educational status: Middle school - High school $(\% 49,6)$, mother's working condition: Not working in any job $(\% 76,9)$, father's working condition: Working $(\% 68,4)$, number of people in the family: $3-4(\% 50,4)$ and monthly family income: Above the min wage level $(\% 46,2)$. In addition to this, there is not found any postgraduate degrees of university students' fathers and mothers.

\subsection{Family Financial Socialization Findings}

Descriptive statistics of the statements in the family financial socialization dimensions are indicated in table 5.

Table 5. Descriptive Statistics for the Statements in the Family Financial Socialization Dimensions

\begin{tabular}{|c|c|c|c|c|c|c|c|c|c|c|c|c|c|c|c|c|}
\hline \multirow{2}{*}{ I } & \multirow{2}{*}{ TS } & \multirow{2}{*}{ M } & \multirow{2}{*}{ SD } & \multirow{2}{*}{ TSM } & \multirow{2}{*}{$\mathbf{M}$} & \multirow{2}{*}{ SD } & \multicolumn{2}{|c|}{ Never } & \multicolumn{2}{|c|}{ Rarely } & \multicolumn{2}{|c|}{ Sometimes } & \multicolumn{2}{|c|}{ Usually } & \multicolumn{2}{|c|}{ Always } \\
\hline & & & & & & & $\mathbf{F}$ & $\%$ & $\mathbf{F}$ & $\%$ & $\mathbf{F}$ & $\%$ & $\mathbf{F}$ & $\%$ & $\mathbf{F}$ & $\%$ \\
\hline 1 & 437 & 3,73 & 1,348 & \multirow{8}{*}{$\begin{array}{l}\stackrel{y}{7} \\
\stackrel{m}{7}\end{array}$} & \multirow{8}{*}{$\hat{n}$} & \multirow{8}{*}{ 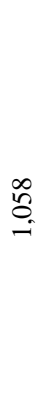 } & 11 & 9,4 & 14 & 12 & 17 & 14,5 & 28 & 23,9 & 47 & 40,2 \\
\hline 2 & 383 & 3,27 & 1,477 & & & & 21 & 17,9 & 17 & 14,5 & 23 & 19,7 & 21 & 17,9 & 35 & 29,9 \\
\hline 3 & 402 & 3,43 & 1,566 & & & & 24 & 20,5 & 10 & 8,5 & 20 & 17,1 & 17 & 14,5 & 46 & 39,3 \\
\hline 4 & 415 & 3,54 & 1,348 & & & & 13 & 11,1 & 14 & 12,0 & 24 & 20,5 & 28 & 23,9 & 38 & 32,5 \\
\hline 5 & 433 & 3,70 & 1,268 & & & & 11 & 9,4 & 8 & 6,8 & 26 & 22,2 & 32 & 27,4 & 40 & 34,2 \\
\hline 6 & 424 & 3,62 & 1,394 & & & & 13 & 11,1 & 14 & 12 & 23 & 19,7 & 21 & 17,9 & 46 & 39,3 \\
\hline 7 & 412 & 3,52 & 1,342 & & & & 12 & 10,3 & 16 & 13,7 & 26 & 22,2 & 25 & 21,4 & 38 & 32,5 \\
\hline 8 & 400 & 3,41 & 1,421 & & & & 17 & 14,5 & 15 & 12,8 & 24 & 20,5 & 24 & 20,5 & 37 & 31,6 \\
\hline 9 & 511 & 4,36 & 0,952 & \multirow{6}{*}{$\begin{array}{l}\mathscr{\infty} \\
\tilde{y} \\
\tilde{y}\end{array}$} & \multirow{6}{*}{$\stackrel{\infty}{\stackrel{\infty}{m}}$} & \multirow{6}{*}{$\begin{array}{l}0 \\
\infty \\
\infty \\
0\end{array}$} & 3 & 2,6 & 3 & 2,6 & 12 & 10,3 & 29 & 24,8 & 70 & 59,8 \\
\hline 10 & 424 & 3,62 & 1,324 & & & & 12 & 10,3 & 12 & 10,3 & 24 & 20,5 & 29 & 24,8 & 40 & 34,2 \\
\hline 11 & 436 & 3,72 & 1,079 & & & & 4 & 3,4 & 14 & 12 & 22 & 18,8 & 47 & 40,2 & 30 & 25,6 \\
\hline 12 & 492 & 4,20 & 1,095 & & & & 5 & 4,3 & 5 & 4,3 & 15 & 12,8 & 28 & 23,9 & 64 & 54,7 \\
\hline 13 & 341 & 2,91 & 1,453 & & & & 26 & 22,2 & 26 & 22,2 & 21 & 17,9 & 20 & 17,1 & 24 & 20,5 \\
\hline 14 & 453 & 3,87 & 1,283 & & & & 9 & 7,7 & 9 & 7,7 & 23 & 19,7 & 23 & 19,7 & 53 & 45,3 \\
\hline
\end{tabular}

* I= Item * TS: Total Score * M: Mean, * SD: Standard Deviation, * TSM: Total Score Mean * F: Frequency

According to the statements in table 5, university students' frequency levels of family financial socialization include:

The great majority of university students $(\% 84,6)$ perceive the statement of "My parents pay their bills on time (I9) " by frequency levels of always $(\% 59,8)$ and usually $(\% 24,8)$.

\%78,6 of university students mainly perceive the statement of “My parents spend by their income (I12)" by frequency levels of always $(\% 54,7)$ and usually $(\% 23,9)$.

$\% 47,8$ of university students modestly perceive the statement of "During my childhood, I used to visit my parents' workplaces. (I2)” by frequency levels of always $(\% 29,9)$ and usually $(\% 17,9)$.

$\% 37,6$ of university students perceive the statement of "My parents used to talk clearly about finance with me as a child (I13)" by frequency levels of always $(\% 20,5)$ and usually $(\% 17,1)$.

As far as dimensions are concerned, both financial experience \& learning (FEL) and money management skills (MMS) are perceived at a high level by university students in terms of mean and total score mean \{FEL: $(3,53)$, $(397,8 \leq 413,25<491,4)$ and MMS: $(3,78),(397,8 \leq 442,83<491,4)\}$. In addition to this, "money management skills" dimension of university students is greater than the dimension of financial experience \& learning.

According to the statements in table 6, university students' participation levels of money attitudes include:

The statement of "In order to avoid interest and penalties, I pay my bills immediately (S16)" is expressed by the great majority of university students $(\% 77,8)$.

The statement of "I follow closely of my money affairs (S15)" is mostly preferred by the \%66,7 of university students.

The statement of "You need money to buy the good things in life (S27)" is moderately perceived by the \%52 of university students. 
Süleyman Demirel Üniversitesi Vizyoner Dergisi, Yıl: 2021, Cilt: 12, Sayı: 30, 393-416.

Süleyman Demirel University Visionary Journal, Year: 2021, Volume: 12, No: 30, 393-416.

The statement of "With a view to persuading people to help me, I like using money (S18)" is not supported by the $\% 81,2$ of university students.

Table 6. Descriptive Statistics for the Statements in the Dimensions of Money Attitudes

\begin{tabular}{|c|c|c|c|c|c|c|c|c|c|c|c|c|c|c|c|c|}
\hline \multirow{2}{*}{ I } & \multirow{2}{*}{ TS } & \multirow{2}{*}{ M } & \multirow{2}{*}{ SD } & \multirow{2}{*}{ TSM } & \multirow{2}{*}{ M } & \multirow{2}{*}{ SD } & \multicolumn{2}{|c|}{$\begin{array}{l}\text { Strongly } \\
\text { Disagree }\end{array}$} & \multicolumn{2}{|c|}{ Disagree } & \multicolumn{2}{|c|}{ Undecided } & \multicolumn{2}{|c|}{ Agree } & \multicolumn{2}{|c|}{$\begin{array}{c}\text { Strongly } \\
\text { Agree }\end{array}$} \\
\hline & & & & & & & $\mathbf{F}$ & $\%$ & $\mathbf{F}$ & $\%$ & $\mathbf{F}$ & $\%$ & $\mathbf{F}$ & $\%$ & $\mathbf{F}$ & $\%$ \\
\hline 1 & 312 & 2,66 & 1,332 & \multirow{10}{*}{$\begin{array}{l}\stackrel{0}{m} \\
\stackrel{0}{m}\end{array}$} & \multirow{10}{*}{$\begin{array}{l}6 \\
i\end{array}$} & \multirow{10}{*}{ aे } & 29 & 24,8 & 27 & 23,1 & 30 & 25,6 & 16 & 13,7 & 15 & 12,8 \\
\hline 2 & 337 & 2,88 & 1,333 & & & & 23 & 19,7 & 25 & 21,4 & 29 & 24,8 & 23 & 19,7 & 17 & 14,5 \\
\hline 3 & 323 & 2,76 & 1,343 & & & & 29 & 24,8 & 22 & 18,8 & 27 & 23,1 & 26 & 22,2 & 13 & 11,1 \\
\hline 4 & 355 & 3,03 & 1,364 & & & & 19 & 16,2 & 24 & 20,5 & 33 & 28,2 & 16 & 13,7 & 25 & 21,4 \\
\hline 5 & 289 & 2,47 & 1,399 & & & & 42 & 35,9 & 23 & 19,7 & 19 & 16,2 & 21 & 17,9 & 12 & 10,3 \\
\hline 6 & 313 & 2,67 & 1,338 & & & & 26 & 22,2 & 33 & 28,2 & 29 & 24,8 & 11 & 9,4 & 18 & 15,4 \\
\hline 7 & 292 & 2,49 & 1,277 & & & & 34 & 29,1 & 29 & 24,8 & 24 & 20,5 & 22 & 18,8 & 8 & 6,8 \\
\hline 8 & 294 & 2,51 & 1,374 & & & & 37 & 31,6 & 28 & 23,9 & 20 & 17,1 & 19 & 16,2 & 13 & 11,1 \\
\hline 9 & 289 & 2,47 & 1,429 & & & & 41 & 35 & 27 & 23,1 & 18 & 15,4 & 15 & 12,8 & 16 & 13,7 \\
\hline 10 & 299 & 2,55 & 1,227 & & & & 30 & 25,6 & 27 & 23,1 & 33 & 28,2 & 19 & 16,2 & 8 & 6,8 \\
\hline 11 & 403 & 3,44 & 1,322 & \multirow{6}{*}{$\begin{array}{l}\stackrel{8}{n} \\
\underset{\sim}{+} \\
+\end{array}$} & \multirow{6}{*}{$\underset{\text { rె }}{\tilde{m}}$} & \multirow{6}{*}{$\stackrel{n}{8}$} & 13 & 11,1 & 14 & 12,0 & 32 & 27,4 & 24 & 20,5 & 34 & 29,1 \\
\hline 12 & 383 & 3,27 & 1,411 & & & & 17 & 14,5 & 20 & 17,1 & 27 & 23,1 & 20 & 17,1 & 33 & 28,2 \\
\hline 13 & 387 & 3,30 & 1,435 & & & & 19 & 16,2 & 18 & 15,4 & 20 & 17,1 & 28 & 23,9 & 32 & 27,4 \\
\hline 14 & 442 & 3,77 & 1,253 & & & & 9 & 7,7 & 12 & 10,3 & 17 & 14,5 & 37 & 31,6 & 42 & 35,9 \\
\hline 15 & 450 & 3,84 & 1,156 & & & & 5 & 4,3 & 12 & 10,3 & 22 & 18,8 & 35 & 29,9 & 43 & 36,8 \\
\hline 16 & 482 & 4,12 & 1,130 & & & & 6 & 5,1 & 6 & 5,1 & 14 & 12,0 & 33 & 28,2 & 58 & 49,6 \\
\hline 17 & 206 & 1,76 & 1,208 & \multirow{5}{*}{ ڤ્તે } & \multirow{5}{*}{$\stackrel{\infty}{=}$} & \multirow{5}{*}{ ơ } & 75 & 64,1 & 15 & 12,8 & 14 & 12,0 & 6 & 5,1 & 7 & 6,0 \\
\hline 18 & 186 & 1,59 & 0,901 & & & & 75 & 64,1 & 20 & 17,1 & 18 & 15,4 & 3 & 2,6 & 1 & 0,9 \\
\hline 19 & 191 & 1,63 & 1,149 & & & & 82 & 70,1 & 13 & 11,1 & 12 & 10,3 & 3 & 2,6 & 7 & 6,0 \\
\hline 20 & 203 & 1,73 & 1,162 & & & & 73 & 62,4 & 21 & 17,9 & 10 & 8,5 & 7 & 6,0 & 6 & 5,1 \\
\hline 21 & 259 & 2,21 & 1,369 & & & & 52 & 44,4 & 23 & 19,7 & 19 & 16,2 & 11 & 9,4 & 12 & 10,3 \\
\hline 22 & 300 & 2,56 & 1,385 & \multirow{6}{*}{$\frac{m}{m}$} & \multirow{6}{*}{$\begin{array}{l}\infty \\
\infty \\
i\end{array}$} & \multirow{6}{*}{$\stackrel{a}{\sigma}$} & 37 & 31,6 & 23 & 19,7 & 25 & 21,4 & 18 & 15,4 & 14 & 12,0 \\
\hline 23 & 290 & 2,47 & 1,256 & & & & 32 & 27,4 & 33 & 28,2 & 25 & 21,4 & 18 & 15,4 & 9 & 7,7 \\
\hline 24 & 268 & 2,29 & 1,218 & & & & 37 & 31,6 & 38 & 32,5 & 21 & 17,9 & 13 & 11,1 & 8 & 6,8 \\
\hline 25 & 397 & 3,39 & 1,319 & & & & 15 & 12,8 & 16 & 13,7 & 20 & 17,1 & 40 & 34,2 & 26 & 22,2 \\
\hline 26 & 381 & 3,25 & 1,421 & & & & 19 & 16,2 & 19 & 16,2 & 22 & 18,8 & 27 & 23,1 & 30 & 25,6 \\
\hline 27 & 388 & 3,31 & 1,529 & & & & 20 & 17,1 & 24 & 20,5 & 11 & 9,4 & 23 & 19,7 & 39 & 33,3 \\
\hline
\end{tabular}

* I= Item * TS: Total Score * M: Mean, * SD: Standard Deviation, * TSM: Total Score Mean * F: Frequency

Descriptive statistics of statements in the money attitudes are showed in table 6.

As to dimensions in table 6, mindful and responsible (MR) is perceived at a high level, both "worries about savings and financial literacy (WSFL)" and "achievement and success (AS)" are perceived at a moderate level and power and status (PS) is perceived lowest by university students based on mean and total score mean $\{$ MR: $(3,62),(397,8 \leq$ 424,50 < 491,4) ; AS: $(2,88),(304,2 \leq 337,33<397,8)$; WSFL: $(2,65),(304,2 \leq 310,30<397,8)$; PS: $(1,78),(117 \leq$ $209<210,6)\}$. Thus, mindful and responsible dimension has the highest scores in comparison with dimensions, such as achievement and success, worries about savings \& financial literacy and power and status, respectively.

\subsection{Findings of Hypothesis Testing}

Hypotheses will be tested through the analyses of correlation, regression and one-way MANOVA in order to reveal relationships, cause and effect relationships and differences in family financial socialization levels and money attitudes of students. 
Süleyman Demirel Üniversitesi Vizyoner Dergisi, Yıl: 2021, Cilt: 12, Sayı: 30, 393-416.

Süleyman Demirel University Visionary Journal, Year: 2021, Volume: 12, No: 30, 393-416.

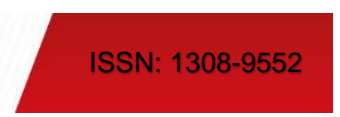

\subsubsection{Relationships between Family Financial Socialization Dimensions and Money Attitudes}

In the light of the data in table 7, statistically significant correlations between variables are detected as follows:

Table 7. Correlations between Research Variables

\begin{tabular}{|c|c|c|c|c|c|c|c|}
\hline I & Variables & 1 & 2 & 3 & 4 & 5 & 6 \\
\hline 1 & Financial Experience and Learning & 1 &, $682 * * *$ &,$- 413 * * *$ &, $234 * *$ &,- 122 &,- 075 \\
\hline 2 & Money Management Skills & & 1 &,$- 215^{* *}$ &, $295 * * *$ &,- 078 &,- 016 \\
\hline 3 & Worries of Savings \& Financial Literacy & & & 1 & ,066 &, $343 * * *$ &, $452 * * *$ \\
\hline 4 & Mindful and Responsible & & & & 1 &,$- 183 * *$ & $214 * *$ \\
\hline 5 & Power and Status & & & & & 1 &, $363 * * *$ \\
\hline 6 & Achievement and Success & & & & & & 1 \\
\hline
\end{tabular}

$* \mathrm{p} \leq 0,10 * * \mathrm{p} \leq 0,05 * * * \mathrm{p} \leq 0,01$ Statistics are significant at $5 \%$ and $1 \%$.

There is a significant negative relationship between university students" "financial experience and learning" and "worries about savings and financial literacy" at the \%1 level $(r=-0,413 \mathrm{p}=0,000 \leq 0,01)$. Besides, university students' "financial experience and learning" is significantly and positively related to "mindful and responsible" dimension of money attitudes at the $\% 5$ level $(r=0,234 ; \mathrm{p}=0,011 \leq 0,05)$. On the other hand, the dimension of financial experience and learning hasn't any significant correlations with power and status as well as achievement and success. Thus, H1(a) and H1(b) are confirmed, however H1(c) and H1(d) are disproved.

University students' the dimension of "money management skills" has a significant negative correlation with "worries about savings and financial literacy" at the $\% 5$ level $(r=-0,215 ; p=0,020 \leq 0,05)$. In addition to this, university students" "money management skills" is significantly and positively correlated to "mindful and responsible" dimension of money attitudes at the $\% 1$ level $(r=0,295 ; \mathrm{p}=0,011 \leq 0,05)$. However, the dimension of money management skills hasn't any significant correlations with power and status as well as achievement and success ( $>$ > 0,05). As a consequence, H2(a) and H2(b) are confirmed; conversely, H2(c) and H2(d) are disproved.

\subsubsection{The Cause and Effect Relationships between Family Financial Socialization Dimensions and Money} Attitudes

As shown in table 8, the cause and effect relationships between independent (x) and dependent (y) variables include:

Table 8. The Simultaneous Effects of Family Financial Socialization Dimensions on Money Attitudes: The Results of Multiple Regression Analysis

\begin{tabular}{|c|c|c|c|c|c|c|c|c|}
\hline $\mathbf{Y}$ & $\mathbf{X}$ & B & $\mathbf{T}$ & $\mathbf{P}$ & $\mathbf{F}$ & Model P & $\mathbf{R}$ & Adjusted R Square \\
\hline & (Constant) & 3,756 & 9,778 & 0,000 & & & & \\
\hline \multirow[t]{3}{*}{ WSFL } & FEL & $-0,468$ & $-4,291$ & $0,000 * * *$ & 12,406 & $0,000 * * *$ & 0,423 & 0,164 \\
\hline & MMS & 0,145 & 1,077 & 0,284 & & & & \\
\hline & (Constant) & 2,219 & 5,120 & 0,000 & & & & \\
\hline \multirow[t]{3}{*}{ MR } & FEL & 0,061 & 0,499 & 0,619 & 5,561 & $0,005 * * *$ & 0,298 & 0,073 \\
\hline & MMS & 0,315 & 2,071 & $0,041^{* *}$ & & & & \\
\hline & (Constant) & 2,251 & 5,373 & 0,000 & & & & \\
\hline \multirow[t]{3}{*}{ PS } & FEL & 0,011 & 0,078 & 0,938 & 0,861 & 0,426 & 0,122 & 0,002 \\
\hline & MMS & $-0,115$ & $-1,011$ & 0,314 & & & & \\
\hline & (Constant) & 2,151 & 6,924 & 0,000 & & & & \\
\hline \multirow[t]{2}{*}{ AS } & FEL & $-0,115$ & $-0,938$ & 0,350 & 0,456 & 0,635 & 0,089 & 0,009 \\
\hline & MMS & 0,078 & 0,511 & 0,610 & & & & \\
\hline $\mathrm{NSF}$ & $56-0,46$ & $+0,1$ & 4S) & $\mathrm{MR}=2,219+\mathrm{c}$ & (FEL) & 15 (MMS) & & \\
\hline
\end{tabular}

$\mathrm{H} 3$ (a) is confirmed, on the grounds that the regression model is significant at the $\% 1$ level $(\mathrm{p}=0,000 \leq 0,01)$. As a matter of fact, \%16,4 ( $\left.\mathrm{R}^{2}=0,164\right)$ of worries about savings and financial literacy (WSFL) dimension is simultaneously explained by financial experience and learning (FEL) and money management skills (MMS). 
Financial experience and learning dimension has a significant effect $(p=0,000 \leq 0,01)$ on worries about savings and financial literacy, on the other hand the dimension of money management skills hasn't a significant effect ( $p$ $>0,05$ ) on worries about savings and financial literacy. As to regression equation, for every one-unit increase in financial experience and learning of university students, the predicted value of students' worries about savings and financial literacy dimension decreases by about 0,468 .

The regression model is significant at the $\% 1$ level, so that $\mathrm{H} 3(\mathrm{~b})$ is confirmed $(\mathrm{p}=0,005 \leq 0,01)$. Indeed, financial experience and learning (FEL) and money management skills (MMS) simultaneously account for \% 7,3 $\left(\mathrm{R}^{2}=\right.$ 0,073 ) of variance in mindful and responsible (MR) dimension. The dimension of money management skills has a significant effect on mindful and responsible $(\mathrm{p}=0,041 \leq 0,05)$, however financial experience and learning dimension hasn't a significant effect on mindful and responsible $(\mathrm{p}>0,05)$. As regards regression equation, for every one-unit increase in money management skills of university students, the predicted value of students' mindful and responsible dimension increases by about 0,315 .

In contrast to the aforementioned determinations, university students" "financial experience and learning" and "money management skills" haven't any significant effects on the "power and status (PS)" as well as "achievement and success (AS)" (p > 0,05). As a result, H3(c) and H3(d) are disproved.

\subsubsection{Differences between Demographic \& Socio-Economic Characteristics and Family Financial Socialization Levels}

Table 9 shows whether there are statistically significant differences between university students' family financial socialization dimensions and demographic and socio-economic characteristics. In this respect, determinations include:

Box's $M$ test is statistically met for these variables which are indicated in table 9 ( $p>0,05)$. Accordingly, preliminary condition for the feasibility of one-way MANOVA is realized.

H4.2. is confirmed owing to statistical significance of the one-way MANOVA model $(\mathrm{p}=0,039 \leq 0,05)$. Furthermore, age factor accounts for \%5,7 $(\eta 2=0,057)$ of variance in the dimensions (financial experience and learning (FEL) and money management skills (MMS)) of family financial socialization. Financial experience and learning and money management skills differ significantly, based on age (FEL (p) $\leq 0,05$; marginally significant for MMS $(p)=0,094 \leq 0,10)$. In comparison with age groups, 25-28 age group of university students, which is detected the root cause of significant differences, has the lowest mean score in both "financial experience and learning" (M: 2,22) and "money management skills" (M: 3,03).

Table 9. The Differences between Demographic and Socio-Economic Characteristics on the Dimensions of Family Financial Socialization: One-Way MANOVA Results

\begin{tabular}{|c|c|c|c|}
\hline \multirow{2}{*}{ Factors } & & \multicolumn{2}{|c|}{ M (SD) } \\
\hline & & FEL & MMS \\
\hline \multirow{5}{*}{ Age } & $18-20$ & $3,62(0,971)$ & $3,66(0,679)$ \\
\hline & $21-24$ & $3,57(1,059)$ & $3,89(0,893)$ \\
\hline & $25-28$ & $2,22(0,686)$ & $3,03(0,828)$ \\
\hline & 29 and above & $3,56(1,856)$ & $3,33(1,414)$ \\
\hline & $\mathrm{F}$ & $2,798 * *$ & $2,185 *$ \\
\hline \multicolumn{4}{|c|}{ Box's M Test: $F=0,967 p=0,447>0,05$}$;\{$ Wilks' $\Lambda=0,889 F=2,253 p=0,039 \leq 0,05 ;$ Partial Eta Squared $=0,057\}$ \\
\hline \multirow{5}{*}{$\begin{array}{l}\text { Mother's } \\
\text { Educational } \\
\text { Status }\end{array}$} & Not any school graduate & $2,29(1,063)$ & $2,77(0,509)$ \\
\hline & Primary school & $3,33(1,049)$ & $3,67(0,869)$ \\
\hline & Middle - High School & $4,01(0,907)$ & $4,06(0,767)$ \\
\hline & University & $3,91(0,882)$ & $4,08(0,743)$ \\
\hline & $\mathrm{F}$ & $5,397 * * *$ & $3,516 * *$ \\
\hline \multicolumn{4}{|c|}{ Box's M Test: $F=0,464 p=0,898>0,05$}$;\{$ Wilks' $A=0,867 F=2,760 p=0,013 \leq 0,05 ;$ Partial Eta Squared $=0,069\}$ \\
\hline
\end{tabular}




\begin{tabular}{|c|c|c|c|}
\hline \multirow{2}{*}{ Factors } & & \multicolumn{2}{|c|}{ M (SD) } \\
\hline & & FEL & MMS \\
\hline \multirow{4}{*}{$\begin{array}{l}\text { Father's } \\
\text { Working } \\
\text { Condition }\end{array}$} & Working & $3,63(1,073)$ & $3,84(0,846)$ \\
\hline & Not working in any job & $3,02(1,129)$ & $3,26(0,873)$ \\
\hline & Retired & $3,48(0,903)$ & $3,90(0,805)$ \\
\hline & $\mathrm{F}$ & 2,028 & $3,122 * *$ \\
\hline \multicolumn{4}{|c|}{ Box's M Test: $F=0,202 p=0,976>0,05$}$;\{$ Roy's $L R=0,055 F=3,147 p=0,047 \leq 0,05 ;$ Partial Eta Squared $=0,052\}$ \\
\hline \multirow{4}{*}{$\begin{array}{l}\text { Monthly Family } \\
\text { Income }\end{array}$} & Below the Minimum Wage Level & $2,50(0,904)$ & $2,92(0,892)$ \\
\hline & Minimum Wage Level & $3,65(0,963)$ & $3,88(0,790)$ \\
\hline & Above the Minimum Wage Level & $3,62(1,077)$ & $3,86(0,827)$ \\
\hline & $\mathrm{F}$ & $6,313 * * *$ & $6,734 * * *$ \\
\hline
\end{tabular}

\footnotetext{
$* \mathrm{p} \leq 0,10 * * \mathrm{p} \leq 0,05 * * * \mathrm{p} \leq 0,01 \quad$ Statistics are significant at $\% 10,5 \%$ and $1 \% . \quad$ M: Mean, SD: Standard Deviation
}

Inasmuch as one-way MANOVA model is statistically significant, H4.4. is confirmed $(\mathrm{p}=0,013 \leq 0,05)$. Indeed, $\% 6,9(\eta 2=0,069)$ of "financial experience and learning (FEL)" and "money management skills (MMS)" are explained by the factor of mother's educational status. Both "financial experience and learning" and "money management skills" differ significantly based on mother's educational status factor (FEL (p) $\leq 0,01$; MMS (p) $\leq$ 0,05). Tukey post-hoc analysis discloses significant differences between "Middle - High school and Not any school graduate" ( $\mathrm{p} \leq 0,05)$ and "Middle - High school and Primary school" ( $\mathrm{p} \leq 0,01)$ for financial experience and learning dimension. Besides, there is a significant difference between "Not any school graduate" and "Middle High school" for money management skills dimension $(\mathrm{p} \leq 0,05)$. In comparison with groups of mother's educational status, "university students whose mothers have not graduated from any school" group has significantly the lowest mean score in both "financial experience and learning" (M: 2,29) and "money management skills" (M: 2,77). As a result, it is considerable that financial experience and learning and money management skills of university students increase in that their mothers' educational statuses increase.

One-way MANOVA model is statistically significant, so that H4.7. is confirmed. ( $p=0,005 \leq 0,01$ ). Moreover, father's educational status factor accounts for $\% 5,2(\eta 2=0,052)$ of variance in the dimensions of family financial socialization. Money management skills (MMS) differ significantly, however financial experience and learning (FEL) dimension doesn't differ significantly, based on father's working condition. Tukey post-hoc analysis reveals that significant differences between "Not working" and "Working" $(\mathrm{p} \leq 0,05)$ and "Not working" and "retired" (marginally significant for $\mathrm{p}=0,066 \leq 0,10$ ) for money management skills. On the other hand, there isn't a significant difference between "working" and "retired" in money management skills $(p>0,05)$. Relative to "retired (M: 3,90)" and "working (M: 3,84)" groups of father's working condition, "university students whose fathers are not working in any job (M: 3,26)" group has significantly the lowest mean score in money management skills.

H4.9. is confirmed, on the grounds that one-way MANOVA model is statistically significant $(\mathrm{p}=0,005 \leq 0,01)$. Indeed, \% 6,3 $(\eta 2=0,063)$ of dimensions of family financial socialization are explained by the factor of monthly family income. Both "financial experience and learning" and "money management skills" differ significantly based on the factor of monthly family income (FEL $(p) \leq 0,01 ; \operatorname{MMS}(p) \leq 0,01)$. Tukey post-hoc analysis discloses that significant differences (at the $\% 1$ level $(\mathrm{p} \leq 0,01)$ ) between "Below the minimum wage level and Minimum wage level" and "Below the minimum wage level and Above the Minimum Wage Level" for financial experience and learning and money management skills. However, there isn't a significant difference between "Minimum wage level" and "Below the minimum wage level" in financial experience and learning $(p>0,05)$ and money management skills $(p>0,05)$. In comparison with groups of monthly family income, "university students' monthly family income which is below the minimum wage level" group has significantly the lowest mean score in both "financial experience and learning" (M: 2,50) and "money management skills" (M: 2,92). It is a notable point that students" "financial experience and learning (FEL)" and "money management skills (MMS)" decrease inasmuch as their monthly family incomes decrease.

Apart from these determinations, "financial experience and learning" and "money management skills" don't differ significantly, based on the factors of "gender, settlement, father's educational status, mother's working condition 
and number of people in the family" ( $p>0,05)$. Thus, hypotheses of H4.1., H4.3., H4.5., H4.6 and H4.8 are disproved.

\subsubsection{Differences between Demographic \& Socio-economic Characteristics and Money Attitudes}

Table 10 indicates statistically significant differences between university students' money attitudes and demographic and socio-economic characteristics.

Box's M test, which is used to determine whether the observed covariance matrices of the dependent variables are equal across groups, is statistically met for money attitude dimensions with the groups of gender, age, mother's educational status and mother's working condition $(p>0,05)$, except monthly family income $(p \leq 0,05)$. In order to analyze the significant differences between money attitude dimensions and monthly family income groups, the test of Pillai's Trace is applied, even though Wilks' $\Lambda$ has a valid significance level $(p \leq 0,05)$. This test is applied for generating robustness of MANOVA in opposition to the violation of equal covariance matrices assumption. Furthermore, Wilks' $\Lambda$ and Roy's LR tests are used to measure differences between money attitude dimensions and other groups of demographic and socio-economic. Thus, for the feasibility of one-way MANOVA analysis preliminary conditions are realized.

According to the p-values in aforementioned tests, money attitudes differ significantly, based on the factors of “gender, age, mother's educational status, mother's working condition and monthly family income at the levels of $\% 10$ (marginally significant for $\mathrm{p}=0,062 \leq 0,10), \% 1(\mathrm{p}=0,000 \leq 0.01), \% 1(\mathrm{p}=0,005 \leq 0.01), \% 10$ (marginally significant for $\mathrm{p}=0,093 \leq 0,10)$ and $\% 5(\mathrm{p}=0,017 \leq 0.05)$, respectively. As a consequence, hypotheses of H5.1., H5.2., H5.4., H5.6 and H5.9. are confirmed. However, money attitudes don't differ significantly, based on the factors of "settlement, father's educational status, father's working condition and number of people in the family ( $p>0,05)$. As a result, hypotheses of H5.3., H5.5., H5.7., H5.8. are disproved. In the light of these general findings, the specific findings include:

Gender factor accounts for $\% 7,6(\eta 2=0,076)$ of variance in the money attitudes. There is a significant difference between females and males in terms of power and status (PS) dimension at the $\% 1$ level $(p \leq 0,01)$. On the other hand, females and males are not significantly different in "worries about savings and financial literacy (WSFL)", "mindful and responsible (MR)" and "achievement and success (AS)". Finally, relative to female university students (M: 1,62), male university students (M: 2,12) score significantly higher in power and status.

$\% 11,1(\eta 2=0,111)$ of the money attitudes are explained by the age factor. "Mindful and responsible (MR)" "power and status (PS)" and "achievement and success (AS)" differ significantly, based on age (marginally significant for $\operatorname{MR}(p)=0,097 \leq 0,10$, PS $(p) \leq 0,01$ and AS $(p) \leq 0,05)$. However, there is not a statistically significant difference between age and worries about savings and financial literacy $(p>0,05)$. In terms of age groups, 18-20 age group (M: 1,63) of university students has significantly the lowest and "29 and above age group (M: 3,80)" has significantly the highest power and status. It is worth mentioning that, university students' power and status dimension of money attitudes increase inasmuch as their ages increase.

The factor of mother's educational status accounts for $\% 12,2(\eta 2=0,122)$ of variance in money attitudes. There is a marginally significant difference between mother's educational status and power and status $(\mathrm{p}=0,068 \leq 0,10)$. On the other hand, there is not a statistically significant difference between mother's educational status and other dimensions of money attitude ( $p>0,05)$. Games-Howell post-hoc analysis reveals significant differences between "Middle - High school" and "Primary school" for power and status dimension ( $\leq 0,05)$. Relative to "students whose mothers have graduated from primary school" group $(\mathrm{M}=1,89)$, "students whose mothers have graduated from middle - high school” group $(\mathrm{M}=1,45)$ scores significantly higher in power and status dimension of money attitudes. 
Süleyman Demirel Üniversitesi Vizyoner Dergisi, Yıl: 2021, Cilt: 12, Sayı: 30, 393-416.

Süleyman Demirel University Visionary Journal, Year: 2021, Volume: 12, No: 30, 393-416.

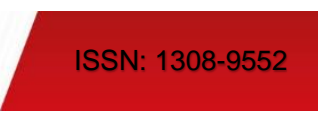

Table 10. The Differences between Demographic and Socio-Economic Characteristics on the Money Attitudes: One-Way MANOVA Results

\begin{tabular}{clcccc}
\hline \multirow{2}{*}{ Factors } & & \multicolumn{4}{c}{ M (SD) } \\
\cline { 3 - 6 } & & WSFL & MR & PS & AS \\
\hline \multirow{3}{*}{ Gender } & Female & $2,57(0,976)$ & $3,72(1,050)$ & $1,62(0,750)$ & $2,86(1,036)$ \\
& Male & $2,81(1,026)$ & $3,42(1,082)$ & $2,12(1,202)$ & $2,92(0,996)$ \\
& F & 1,481 & 2,147 & $7,682 * * *$ & 0,096
\end{tabular}

$\{$ Box's M Test: $F=1,822 p=0,051>0,05\} ;\{$ Wilks' $\Lambda=0,924 F=2,307 p=0,062 \leq 0,10 ;$ Partial Eta Squared $=0,076\}$

\begin{tabular}{|c|c|c|c|c|c|}
\hline \multirow{5}{*}{ Age } & $18-20$ & $2,42(0,869)$ & $3,47(1,107)$ & $1,63(0,664)$ & $3,04(1,038)$ \\
\hline & $21-24$ & $2,70(1,011)$ & $3,76(1,010)$ & $1,73(0,911)$ & $2,75(0,972)$ \\
\hline & $25-28$ & $3,30(1,437)$ & $2,80(1,340)$ & $2,72(1,741)$ & $4,10(1,031)$ \\
\hline & 29 and above & $2,75(0,636)$ & $2,75(0,824)$ & $3,80(0,848)$ & $2,41(0,117)$ \\
\hline & $\mathrm{F}$ & 1,345 & $2,159 *$ & $5,585 * * *$ & $3,434 * *$ \\
\hline \multicolumn{6}{|c|}{ 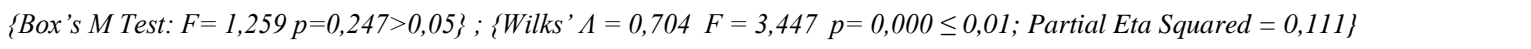 } \\
\hline \multirow{5}{*}{$\begin{array}{l}\text { Mother's } \\
\text { Educational } \\
\text { Status }\end{array}$} & Not any school graduate & $2,86(0,737)$ & $3,05(0,769)$ & $2,53(1,724)$ & $2,77(0,509)$ \\
\hline & Primary school & $2,79(1,027)$ & $3,53(1,101)$ & $1,89(0,999)$ & $2,87(1,115)$ \\
\hline & Middle - High School & $2,34(0,948)$ & $3,92(0,999)$ & $1,45(0,672)$ & $2,92(0,871)$ \\
\hline & University & $2,60(0,635)$ & $3,44(0,922)$ & $1,90(0,874)$ & $2,83(0,906)$ \\
\hline & $\mathrm{F}$ & 1,665 & 1,426 & $2,435 *$ & 0,033 \\
\hline \multicolumn{6}{|c|}{ Box's M Test: $F=1,521 p=0,068>0,05$}$;\{$ Roy's $L R=0,139 F=3,878 p=0,005 \leq 0,01 ;$ Partial Eta Squared $=0,122\}$ \\
\hline \multirow{4}{*}{$\begin{array}{l}\text { Mother's } \\
\text { Working } \\
\text { Condition }\end{array}$} & Working & $2,89(1,010)$ & $3,98(1,021)$ & $1,85(0,979)$ & $3,38(1,089)$ \\
\hline & Not working in any job & $2,57(0,987)$ & $3,52(1,066)$ & $1,75(0,934)$ & $2,74(0,962)$ \\
\hline & Retired & $3,20-$ & $3,33-$ & $3,20-$ & $2,50-$ \\
\hline & $\mathrm{F}$ & 1,205 & 1,944 & 1,249 & $4,301 * *$ \\
\hline \multicolumn{6}{|c|}{ Box's M Test: $F=0,860 p=0,571>0,05$}$;\{$ Wilks' $\Lambda=0,886 F=1,729 p=0,093 \leq 0,10 ;$ Partial Eta Squared $=0,059\}$ \\
\hline \multirow{4}{*}{$\begin{array}{l}\text { Monthly Family } \\
\text { Income }\end{array}$} & Below the Minimum Wage Level & $3,37(0,877)$ & $3,54(0,966)$ & $1,72(0,722)$ & $2,51(0,743)$ \\
\hline & Minimum Wage Level & $2,66(0,941)$ & $3,80(0,976)$ & $1,81(1,048)$ & $2,90(1,063)$ \\
\hline & Above the Minimum Wage Level & $2,49(1,017)$ & $3,47(1,156)$ & $1,76(0,895)$ & $2,93(1,025)$ \\
\hline & $\mathrm{F}$ & $3,514 * *$ & 1,422 & 0,058 & 0,838 \\
\hline
\end{tabular}

$* \mathrm{p} \leq 0,10 * * \mathrm{p} \leq 0,05 * * * \mathrm{p} \leq 0,01 \quad$ Statistics are significant at $\% 10,5 \%$ and $1 \%$.

M: Mean, SD: Standard Deviation

The factor of mother's working condition accounts for $\% 5,9(\eta 2=0,059)$ of variance in the money attitudes. There is a significant difference between mother's working condition and achievement and success $(p \leq 0,05)$. On the other hand, there is not a statistically significant difference between mother's working condition and other dimensions of money attitude ( $\mathrm{p}>0,05)$. Relative to "retired (M: 2,50)" and "not working in any job (M: 2,74)" groups of mother's working condition, "university students whose mothers are working (M: 3,38)" group has significantly the highest mean score in achievement and success. It is considerable that university students' achievement and success dimension of money attitudes increases in that their mothers are working.

$\% 7,8(\eta 2=0,078)$ of the money attitudes are explained by the factor of monthly family income. Worries about savings and financial literacy (WSFL) differ significantly, based on monthly family income ( $\leq \leq 0,05)$. However, there is not a statistically significant difference between monthly family income and other dimensions of money attitude ( $>0,05)$. Tukey post-hoc analysis discloses significant differences between "Below the minimum wage level and Minimum wage level" (Marginally significant: $p=0,075 \leq 0,10$ ) and "Below the minimum wage level and Above the minimum wage level" $(\mathrm{p} \leq 0,05)$ in worries about savings and financial literacy dimension. In terms of monthly family income, "below the minimum wage level" (M: 3,37) group has significantly the highest and "above the minimum wage level" (M: 2,49) group has significantly the lowest worries about savings and financial 
literacy. It is a notable result that students' worries about savings and financial literacy increase inasmuch as their monthly family incomes decrease.

\section{CONCLUSION AND DISCUSSION}

In the line with research problem, research questions and hypotheses, notable results were obtained. These results were evaluated as follows:

What are the family financial socialization levels of university students? With respect to this research question, it was detected that both financial experience \& learning and money management skills were perceived at a high level by university students. Relative to financial experiences and learning of students, their money management skills scored slightly higher. From this standpoint, students' family financial socialization levels could be interpreted:

Majority of the students perceived that their parents paid their bills on time, spent by their income, cared about financial issues, used to encourage them to save money in their childhood and have been taught them how to be a smart consumer since their childhood. In addition to this, most of the students stated that they learned financial matters from observing their parents' money managements in their childhoods. As a matter of fact, it was detected that students were aware of the extent to which they had "financial experiences and learning" and "money management skills" which were brought in their families.

What are the dominant money attitudes of university students? In regard to this research question, it was observed that mindful and responsible dimension was perceived at a high level, both "worries about savings and financial literacy" and "achievement and success" were perceived at a moderate level and power and status dimension was perceived lowest by university students. Thus, in comparison with other dimensions of money attitude, particularly mindful and responsible dimension was ascertained to have the highest score. In this respect, students' money attitudes could be evaluated:

Majority of the students emphasized that in order to avoid interest and penalties they paid their bills immediately, followed closely of their money affairs and saving money for the dark day were crucial to them. It was a notable result that most students perceived money as a mindful and responsible attitude which acted like a protective shield against changes in their lives and also made they feel that they were not owed to people who wanted to control them.

Is there a statistically significant relationship between university students' family financial socialization dimensions and money attitudes? In this context, it was found that "financial experience and learning" dimension was significantly negatively correlated with worries about savings and financial literacy, positively with mindful and responsible, excepted for the dimensions of power and status and achievement and success. Thus, H1(a) and H1(b) are accepted; however H1(c) and H1(d) are rejected. It was detected that money management skills dimension was significantly negatively related to worries about savings and financial literacy, significantly positively to mindful and responsible, excepted for the dimensions of power and status and achievement and success. Hence, the hypotheses of "H2(a) and H2(b)" are accepted; while H2(c) and H2(d) are rejected.

The problem of this research is to what extent dimensions of family financial socialization which consist of financial experience and learning and money management skills of university students have simultaneous significant effects on their money attitudes. In this respect, multiple regression analyse revealed that financial experience and learning and money management skills together as a group, they significantly negatively predicted worries about savings and financial literacy, positively predicted mindful and responsible, excepted for the dimensions of power and status and achievement and success. Thus, the hypotheses of "H3(a) and H3(b)" are accepted; whereas H3(c) and H3(d) are rejected. Furthermore, it was observed that financial experience and learning dimension had a significant negative effect on "worries about savings and financial literacy" and also money management skills had a significant positive effect on "mindful and responsible". These results could be evaluated as follows:

It was found that students' worries about savings and financial literacy decreased inasmuch as their financial experiences and learning increased. The reason was that most of the university students were likely to aware of extent to which their parents were capable of handling financial affairs and also their parents had experiences and 
knowledges about financial issues. In this way, it was found a decrease in students' "worries about savings \& financial literacy" which felt themselves ignorant, with regard to financial matters.

It was ascertained that students' mindful and responsible attitude increased in that their money management skills increased. The reason was that most of the university students were highly likely to perceive of extent to which their parents had skills for managing financial problems, spending by their income, regularly saving money, making a savings plan and making payments on time. Thus, it was found an increase in students' attitude of "mindful and responsible" which saved and invested money for feeling safe and not to be controlled by others.

Do the family financial socialization dimensions of the university students differ significantly, based on their demographic and socio-economic characteristics? In regard to this research question, it was observed that family financial socialization dimensions differ significantly, based on the factors of "age, mother's educational status, father's working condition and monthly family income", except for gender, settlement, father's educational status, mother's working condition and number of people in the family". Accordingly, the hypotheses of H4.2., H4.4., H4.7. and H4.9. were accepted; however H4.1. H4.3. H4.5. H4.6 and H4.8 were rejected.

Interesting and surprising results were obtained for the differences between age and financial socialization dimensions. It is expected that if the age increases, financial experience and learning" and "money management skills" increase. On the other hand, it was detected that relative to not only 21-24 age group but also 18-20 age group; "25-28" age group of university students scored lowest in financial experience and learning and money management skills. Apart from this result, it is known that parents have different attitudes about when to teach children financial issues. According to the study conducted by Danes (1994), parents believe that children between the ages of 12-14 and 15-17 are ready to participate in family financing.

It was a considerable result that financial experience and learning and money management skills of university students increased inasmuch as their mothers' educational statuses increased. This result has been corroborated with previous studies. In the study conducted by Kowalczyk and Chudzian (2015), it was revealed that people who grew up in families who often talked about financial issues had a more rationalist attitude towards money, and children of families who did not draw attention to financial issues displayed a more extravagant attitude towards money. According to Lee and Mortimer (2009), family socialization, especially the family's communication with children on business and money, is an important factor in the development of one's economic self-efficacy. This situation also contributes to the financial independence of the person in adulthood. In the study, people with socioeconomically advantageous family backgrounds (with high income and education level of the family) still register for education, postponing marriage and parenting. People with good family background and academic performance have more confidence in their economic future. In this respect, economic socialization in the family is important for financial independence and self-efficacy. Finally, Cwynar et al., (2009) suggested that the role of parents was not different in the financial socialization process; however families with low financial literacy were inadequate in teaching children about financial issues.

It was a notable point that students" "financial experience and learning" and "money management skills" decreased inasmuch as their monthly family incomes decreased. This result has been corroborated with previous study. Economic behaviour of children varies according to the socioeconomic status of the families. Families with low incomes are more concerned about their children's ability to acquire effective and productive money habits. Those with less income pay more attention to money education. The reason is that, less income requires tighter money management (Furnham and Milner, 2017).

Do the money attitudes of the university students differ significantly, based on their demographic and socioeconomic characteristics? In this respect, it was detected that money attitudes differ significantly, based on the factors of "gender, age, mother's educational status, mother's working condition and monthly family income", except for settlement, father's educational status, father's working condition and number of people in the family". Hence, the hypotheses of H5.1., H5.2., H5.4., H5.6 and H5.9. were accepted; however H5.3., H5.5., H5.7., H5.8 were rejected.

In comparison with female university students, male university students scored significantly higher in power and status. This result on gender has been corroborated with previous study (Lay and Furnham, 2018). Falahati and Paim (2011), found that male students regarded money as a symbol of power and prestige and anxiety levels of male students about money was higher. Women were found to be more conservative to money. In the research conducted by Kowalczyk and Chudzian (2015), men were more careful about money than women and showed a 
more rational attitude. Other side Furnham, Stumm and Fenton-O'creevy (2014), found that women were more generous about money than men, while men saved more money, women did more emotional shopping and money for men represented more power and security than women. Chui and Sidin (2011), revealed that women see money as a symbol of status and success, so they spend more for status such as dresses, jewelry and holidays.

Another result was that, university students' power and status dimension of money attitudes increased inasmuch as their ages increased. This result is incongruent with previous studies. In the study conducted by Lay and Furnham (2018), age factor was found negatively related to power and status. Roberts and Cesar (1999), found that people were more anxious about money as their financial imperatives, such as care for children and other family members, retirement expenses increase as they age.

It was detected that students' worries about savings and financial literacy increased inasmuch as their monthly family incomes decreased. Apart from this result, high income people tend to see money as a symbol of success (Tang, 1992). According to Gasiorowska's (2015), study, those with low income perceive money as a source of success and power and consider money as the source of evil and anxiety. Klontz, Seay, Sullivan and Canale (2014), examined the financial psychology of people with high incomes. Accordingly, they investigated which psychological and behavioural factors determined the high income level. According to the research, people with high incomes showed less money avoidance and less money worship attitude and saw money as a more status symbol. Those who saw money as a status symbol had higher income levels. In the research carried out by Kowalczyk and Chudzian (2015), it was revealed that people who were raised in families with good financial status were more wasteful about money, used money as a tool to buy happiness and did not save money. In a study by Roberts and Cesar (1999), it was revealed that people with high income levels made more careful plans for the future. Doğan and Torlak (2014), revealed that those with high income were more materialistic about money. In the study by Fenton-O'Creevy and Furnham (2019), it was found that the attitude of money, financial ability and financial distress differ according to the income dimension. On the other hand, Yamauchi and Templer (1982), did not find a difference between income and money attitude. The socio-economic status of childhood is considered as an important factor for the financial and professional success of adults and better health conditions. In addition, income is also affected by financial information and education (Roberts, Kuncel, Shiner, Avsalom and Goldberg, 2007; Klontz et al., 2014: 46).

\section{LIMITATIONS AND RECOMMENDATIONS}

First, the research is limited to students studying at the Banking and Finance Department of Zonguldak Bülent Ecevit University School of Applied Sciences. However, other departments, faculties, school of applied sciences, vocational schools, universities and also other sectors are not involved in this research. Compared to other sectors, particularly students studying at the university are considered in this research because of easier accessibility to respondents, lower research costs, greater convenience for empirical research in education and higher applicability of the research model. Students studying banking and finance department are the future financial advisors, financial intermediaries, international bankers, budget analysts, accountants, investor relations associates and financial managers. Financing decisions (procurement of resources), investment decisions (efficient use of provided resources) and dividend decisions are literally money management. Students first learn about money management from their families and also their parents shape and develop their financial experiences and learning. Furthermore, financial education programs at universities aid them to improve money attitudes. Therefore, this study area is surveyed. Although total count method is used in this study, the total population size needs to be expanded in order to determine whether the family financial socialization levels and money attitudes of the students differ in terms of number of people. Moreover, other departments (social sciences, natural sciences and health sciences) and sectors (insurance, industry and trade) may be included in future research to measure the effectiveness of the research results. Second, the research is limited to the use of the survey technique among data collection techniques. Finally, study is limited to research questions. Additionally, interview technique may be used with survey and it might be improved of research questions. For the future researchers, it might be desirable to investigate the cultural differences and the factors of "silence, emotional intelligence, financial personality and financial risk tolerance" in connection with family financial socialization and money attitudes. 


\section{DECLARATION OF THE AUTHORS}

Declaration of Contribution Rate: The first author is responsible for the literature review and data collection while the second author is responsible for the determination of the method, analysis and the reporting of the findings. The first author contributes $50 \%$ while the second author contributes $50 \%$.

Declaration of Support and Thanksgiving: No support is taken from any institution or organization. We would like to thank to the Ethics Committee of Zonguldak Bülent Ecevit University for giving written approval for data collection from students. We would like to thank to the university students for completely responding research questionnaire. We would like to thank to the Süleyman Demirel University Visionary Journal for creating respectable and valuable international scientific platform where noteworthy academic articles are voiced by means of your selective and meticulous efforts.

Declaration of Conflict: There is no potential conflict of interest in the study.

\section{REFERENCES}

Antoni, Z.L., Rootman, C. and Struwig, FW. (2019). The influence of parental financial socialisation techniques on student financial behaviour. International Journal of Economic and Finance Studies, 11(2), 72-88. doi: 10.34109 / İJEFS.201911205.

Bowen, C. F. (2002). Financial knowledge of teens and their parents. Financial Counselling and Planning, 13(2), 93-101.

Chui, C. T. B. and Sidin, S. Md. (2011). Satisfying women's status desires: Role of money attitude and consumer vanity in status consumption. Asia Pacific Advances in Consumer Research, 9(329), 328-335.

Cwynar, A., Cwynar, W., Baryla-Matejczuk, M. and Betancort, M. (2019). Sustainable debt behavior and wellbeing of young adults: The role of parental financial socialisation process. Sustainability, 11(24), 1-26. doi: 10.3390 / su1 1247210 .

Danes, S. M. (1994). Parental perception of children's financial socialization. Counselling and Planning, 5, $127-$ 146, Access address: https://www.afcpe.org/wp-content/uploads/2018/10/vol-58-1.pdf, (04.05.2020).

Dilworth, J. L., Chenoweth, L. C. and Engelbrecht, J. (2000). A qualitative study of the money goals of college students and their parents. Financial Counselling and Planning, 11(2), 33-42.

Doğan, V. and Torlak, Ö. (2014). The relationship between symbolic money meanings and materialism. Business and Economics Research Journal, 5(2), 1-17.

Dowling, N. A., Corney, T. and Hoiles, L. (2009). Financial management practices and money attitudes as determinants of financial problems and dissatisfaction in young male Australian workers. Journal of Financial Counselling and Planning, 20(2), 5-13.

Falahati, L. and Paim, L. H. (2011). A comparative study in money attitude among university students: A gendered view. Journal of American Science, 7(6), 1144-1148.

Fenton-O'Creevy, M. and Furnham, A. (2019). Personality, ideology, and money attitudes as correlates of financial literacy and competence. Financial Planning Review, 3(1), 1-14. doi: 10.1002/cfp2.1070.

Furnham, A. (1984). Many sides of the coin: The psychology of money usage. Personality and Individual Differences, 5(5), 501-509.

Furnham, A. (2019). The personality disorders and money beliefs and behaviors. Financial Planning Review, 2(5), 1-9. doi: $10.1002 / \mathrm{cfp} 2.1046$.

Furnham, A. and Milner, R. (2017). Parent's beliefs and behaviors about the economic socialisation, through allowances/pocket money of their children. Scientific Research Publishing, 8(8), 1216-1228.

Furnham, A., Stumm, S. and Fenton-O' Creevy, M. (2014). Sex differences in money pathology in the general population. Social Indicators Research, 123(3), 701-711. doi: 10.1007/s11205-014-0756-X. 
Furnham, A., Stumm, S. and Milner, R. (2014). MoneyGrams: Recalled childhood memories about money and adult money pathology. Journal of Financial Therapy, 5(1), 40-54. doi: 10.414/1944-9771.1059.

Garrison, S. T. (2010). Gender differences in financial socialization and willingness to take financial risks. (Unpublished master's thesis), University of Florida.

Gasiorowska, A. (2015). The impact of money attitudes on the relationship between income and financial satisfaction. Polish Psychological Bulletin, 46(2), 197-208. doi: 10.1515/ppb-2015-0026.

Gasiorowska, A. and Helka, A. M. (2012). Psychological consequences of money and money attitudes in dictator game. Polish Psychological Bulletin, 43(1), 20-26. doi: 10.2478/v10059-012-0003-8.

Glenn, C. E. (2018). The influence of financial socialization on young adults. Doctoral Dissertation, Personal Financial Planning College of Human Ecology, Kansas State University, Manhattan, Kansas.

Gudmunson, C. G. and Danes, S. M. (2011). Family financial socialization: Theory and critical review. Journal of Family and Economic Issues, 32(4), 644-667. doi: 10.10077s10834-011-9275-y.

Hilgert, M. A., Hogart, J. M. and Beverly, S. G. (2003). Household financial management: The connection between knowledge and behavior. Federal Reserve Bulletin, 89(7), 309-322.

Juneman, A., Eko, M., and Wahyu, R. (2012). Symbolic meaning of money, self-esteem, and identification with Pancasila values. Social and Behavioral Sciences, 65, 106-115. doi: 10.10167J.sbspro.2012.11.099.

Kim, J. and Chatterjee, S. (2013). Childhood financial socialization and young adults' financial management. Journal of Financial Counseling and Planning, 24(1), 61-79.

Klontz, B. T., Bivens, A., Klontz, P.T., Wada, J. and Kahler, R. (2008). The treatment of disordered money behaviors: Results of an open clinical trial. Psychological Services, 5(3), 295-308. doi: 10.1037/15411559.5.3.295.

Klontz, B. T., Britt, S. L. and Mentzer, J. (2011). Money beliefs and financial behaviors: Development of the Klontz money script inventory. Journal of Financial Therapy, 2(1), 1-22. doi: 10.4148/jft.v2i.451.

Klontz, B. T., Seay, M. C., Sullivan, P. and Canale, A. (2014). The psychology of wealth: Psychological factors associated with high income. Journal of Financial Planning, 27(12), 46-53.

Klontz, B., Britt, S., L. Archulate, K. L. and Klontz, T. (2012). Disordered money behaviors: development of the Klontz money behavior inventory. Journal of Financial Therapy, 3(1), 17-42. doi: 10.4148/jt.v3i1.1485.

Kowalczyk, A. and Chudzian, J. (2015). Money attitudes vs. Economic socialization in Poland. Review of Agricultural and Applied Economics, 18(1), 11-18. doi: 10.15414/raae.20155.18.01.11-18.

Lay, A. and Furnham, A. (2018). A new money attitudes questionnaire. European Journal of Psychological Assessment, 35(6), 813-822, Advance online publication. 1-10. Access address: http://dx.doi.org/10.1027/1015-5759/a000474, (01.05.2020).

Lee, J. C. and Mortimer, J., T. (2009). Family socialization, economic self-efficacy and the attainment of financial independence in early adulthood. Longitudinal and Life Course Studies, 1(1), 45-62.

Mitchell, T. R. and Mickell, A. E. (1999). The meaning of money: An individual-difference perspective. Academy of Management Review, 24(3), 568-578.

Moreno, C. P., Salcedo, M., Rebellon, M. F. and Anzelin, I. (2018). An approach to the economic socialization of university students: The origin, uses and meaning on money. International Educations Studies, 11(7), 1913-9039. doi: 10.5539/ies.v11n7p92.

Ramirez, R. M. and Torres, V. (2014). From one generation to the next: The role of parents in the financial inclusion of young people. Freedom from Hunger Mastercard Foundation. Access address: https://www.findevgateway.org/paper/2014/05/one-generation-next-role-parents-financial-inclusionyoung-people, (01.05.2020). 
Roberts, B. W., Kuncel, N. R., Shiner, R. L., Avshalom, C., and Goldberg, L. R. (2007). The power of personality the comparative validity of personality traits, socioeconomic status, and cognitive ability for predicting important life outcomes. Perspective on Psychological Science, 2(4), 313-345. doi: 101111/j.17456916.2007.00047.x.

Roberts, J. A. and Cesar, J., S., M. (1999). Demographics and money attitudes: A test of Yamauchi and Templer's (1982) money attitude scale in Mexico. Personality and Individual Differences, 27(1), 19-35. doi: 10.1016/S0191-8869(98)00241-4.

Roberts, J. A. and Jones, E. (2001). Money attitudes, credit card use and compulsive buying among American college students. The Journal of Consumer Affairs, 35(2), 213-240. doi: 10.1111/j.17456606.2001.tb00111.x.

Solheim, C. A., Zuiker, V. S. and Levchenko, P. (2011). Financial socialization family pathways: Reflections from college students' narratives. Family Science Review, 16(2), 97-112.

Stumm, S., Fenton-O'Creevy, M. and Furnham, A. (2013). Financial capability, money attitudes and socioeconomic status: Risks for experiencing adverse financial events. Personality and Individual Differences, 54(3), 344-349. doi: 10.1016 / j.paid2012.09.019.

Taneja, R. M. (2012). Money attitude-an abridgement. Researchers World Journal of Arts, Science \& Commerce, 3(3), 94-98.

Tang, T. L. (1992). The meaning of money revisited. Journal of Organizational Behavior. 13(2), 197-202. doi: 10.1002/job.4030130209.

Tang, T. L. and Chiu, R. K. (2003). Income, money ethic, pay satisfaction, commitment, and unethical behavior: Is the love money the root of evil for Hong Kong employees?. Journal of Business Ethics, 46(1), 13-30. doi: 10.1023 / A: 1024731611490.

Yamauchi, K. T. and Templer, D. I. (1982). The development of a money attitude scale. Journal of Personality Assessment, 46 (5), 522-528. doi: 10.1207 / s15327752jpa4605_14.

Zhou, X., Vohs, K. D. and Baumeister, R. F. (2009). The symbolic power of money: Reminders of money alter social distress and physical pain. Psychological Science, 20(6), 700-706. doi: 10.1111/j.14679280.2009.02353.x. 